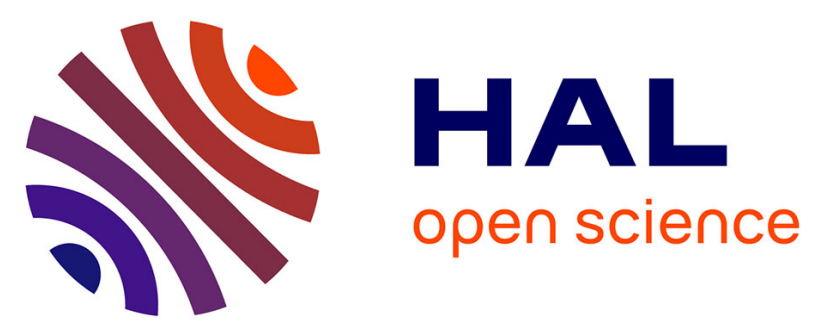

\title{
Southern Ocean link between changes in atmospheric CO2 levels and northern-hemisphere climate anomalies during the last two glacial periods
}

Julia Gottschalk, Luke C. Skinner, Samuel L. Jaccard, Laurie C. Menviel, Christoph Nehrbass-Ahles, Claire Waelbroeck

\section{To cite this version:}

Julia Gottschalk, Luke C. Skinner, Samuel L. Jaccard, Laurie C. Menviel, Christoph Nehrbass-Ahles, et al.. Southern Ocean link between changes in atmospheric CO2 levels and northern-hemisphere climate anomalies during the last two glacial periods. Quaternary Science Reviews, 2020, 230, pp.106067. 10.1016/j.quascirev.2019.106067 . hal-02407224

\section{HAL Id: hal-02407224 \\ https://hal.science/hal-02407224}

Submitted on 30 Nov 2021

HAL is a multi-disciplinary open access archive for the deposit and dissemination of scientific research documents, whether they are published or not. The documents may come from teaching and research institutions in France or abroad, or from public or private research centers.
L'archive ouverte pluridisciplinaire HAL, est destinée au dépôt et à la diffusion de documents scientifiques de niveau recherche, publiés ou non, émanant des établissements d'enseignement et de recherche français ou étrangers, des laboratoires publics ou privés. 

mate anomalies during the last two glacial periods

Julia Gottschalk ${ }^{1,2,3}$ (corresponding author: jgottsch@1deo.columbia.edu), Luke C. Skinner ${ }^{1}$, Samuel L. Jaccard $^{2}$, Laurie Menviel ${ }^{4}$, Christoph Nehrbass-Ahles ${ }^{5}$, Claire Waelbroeck ${ }^{6}$

${ }^{1}$ Godwin Laboratory for Palaeoclimate Research, Department of Earth Sciences, University of Cambridge, Cambridge, UK; ${ }^{2}$ Institute of Geological Sciences and Oeschger Center for Climate Change Research, University of Bern, Bern, Switzerland; ${ }^{3}$ Lamont-Doherty Earth Observatory, Columbia University, Palisades, New York, USA; ${ }^{4}$ Climate Change Research Centre, PANGEA, University of New South Wales, Sydney, New South Wales, Australia; ${ }^{5}$ Climate and Environmental Physics, Physics Institute, and Oeschger Center for Climate Change Research, University of Bern, Bern, Switzerland; 'Laboratoire des Sciences du Climat et de l'Environnement, LSCE/IPSL, CNRS-CEA-UVSQ, Université de Paris-Saclay, Gif-sur-Yvette, France

Abstract

Past millennial-scale changes in atmospheric $\mathrm{CO}_{2}\left(\mathrm{CO}_{2, \text { atm }}\right)$ levels have often been attributed to variations in the overturning timescale of the ocean that result in changes in the marine carbon inventory. There remains a paucity of proxy evidence that documents changes in marine carbon storage globally, and that links them to distinct abrupt climate variability in the northern hemisphere that involve perturbations of the Atlantic Meridional Overturning Circulation (AMOC). The last two glacial periods were suggested to differ in the spatial extent of the AMOC and its sensitivity to perturbations. This provides an opportunity to study the nature of marine carbon cycling during these two climate intervals. Here, we reconstruct variations in respired carbon storage (via oxygenation) and the AMOC 'geometry' (via carbonate ion saturation) in the deep South Atlantic. We infer decreases in deep South Atlantic respired carbon levels at times of weakened $\mathrm{AMOC}$ and rising $\mathrm{CO}_{2, \text { atm }}$ concentrations during both glacial periods. These findings suggest a consistent pattern of increased Southern Ocean convection and/or air-sea $\mathrm{CO}_{2}$ fluxes during northern-hemisphere stadials accompanying AMOC perturbations and promoting a rise in $\mathrm{CO}_{2, \text { atm }}$ levels. We find that net ocean carbon loss, and hence the magnitude of $\mathrm{CO}_{2, \text { atm }}$ rise, during a glacial is largely determined by the stadial duration. North Atlantic climate anomalies may therefore significantly affect Southern Ocean carbon cycling through oceanic (e.g., 'ventilation' seesaw) and/or atmospheric processes (e.g., Ekman pumping). (250 words)

Keywords: Glacials; Paleoclimatology; Southern Ocean; Redox-sensitive elements; Carbon cycle; Foraminifera; Dansgaard-Oeschger cycles; Atmospheric $\mathrm{CO}_{2}$ variations; Stadials; Interstadials

\section{Introduction}


Changes in the concentration of $\mathrm{CO}_{2}$ in the atmosphere $\left(\mathrm{CO}_{2, \mathrm{~atm}}\right)$ recorded in Antarctic ice cores have been found to be tightly linked with Antarctic temperature-proxies over the past eight glacialinterglacial cycles (e.g., Fischer et al., 2010). This link can be partly explained by the radiative forcing imparted by $\mathrm{CO}_{2, \text { atm }}$ (i.e., the greenhouse effect; e.g., Köhler et al., 2017), and by the temperature dependence of processes governing global ocean- and land-atmosphere $\mathrm{CO}_{2}$ exchange, such as the ocean $\mathrm{CO}_{2}$ solubility (Bacastow, 1996; Bereiter et al., 2018), metabolic rates of plants and phytoplankton (Eppley, 1972; Policy et al., 1993; Matsumoto, 2007) and organic carbon respiration rates in the ocean (Matsumoto, 2007; Matsumoto et al., 2007; Kwon et al., 2009). However, this link is also thought to rely on a variety of biogeochemical and hydrographic feedback mechanisms that affect the deep- and surface ocean's total carbon- and alkalinity levels (e.g., Sigman and Boyle, 2000; Hain et al., 2010; Cartapanis et al., 2018). The ocean's sizeable carbon reservoir exchanges with the atmosphere on centennial- to millennial timescales, in particular through vertical mixing and Ekman pumping in the Southern Ocean (Primeau, 2005; Marinov et al., 2006; Gebbie and Huybers, 2011). Other potential carbon sources/sinks that may have influenced $\mathrm{CO}_{2, \text { atm }}$ concentrations on these timescales include the terrestrial biosphere (Köhler et al., 2005; Menviel et al., 2008; Bozbiyik et al., 2011), Arctic permafrost (Zech, 2012; Köhler et al., 2014; Tesi et al., 2016) and the mantle/lithosphere (Huybers and Langmuir, 2009; Broecker et al., 2015; Lund et al., 2016). The Southern Ocean bears a strong leverage on the efficiency of ocean-atmosphere gas exchange (i.e., the "ocean $\mathrm{CO}_{2}$ solubility pump") and on the global-ocean pre-formed versus respired nutrient ratio (i.e., the "soft-tissue/organic carbon pump"), while also influencing global-ocean alkalinity (i.e., the "hard-tissue/carbonate pump"). The Southern Ocean is therefore assumed to play a dominant role in past $\mathrm{CO}_{2, \text { atm }}$ changes (Sarmiento and Toggweiler, 1984; Volk and Hoffert, 1985; Broecker et al., 1999; Sigman and Boyle, 2000; Ito and Follows, 2005; Fischer et al., 2010; Hain et al., 2010; Sigman et al., 2010).

Proxy evidence from the Southern Ocean covering the last glacial cycle strongly supports this view. The glacial Antarctic Zone of the Southern Ocean, south of the Polar Front (Fig. 1), has yielded proxy evidence for reduced vertical mixing and stronger water column density stratification during peak glacial periods, suggesting increased carbon sequestration from the atmosphere (e.g., François et al., 1997; Skinner et al., 2010; Jaccard et al., 2013; Roberts et al., 2015; Studer et al., 2015). In addition, an extended seasonal Antarctic sea ice zone during these intervals may have curbed air-sea gas exchange (Stephens and Keeling, 2000; Gersonde et al., 2003; Benz et al., 2016) and may have stimulated increased export production of organic carbon (Abelmann et al., 2015), both acting to further decrease $\mathrm{CO}_{2, \mathrm{~atm}}$. In the sub-Antarctic Zone between the sub-Antarctic and sub-Tropical Front (Fig. 1), enhanced supply of aeolian dust that may have alleviated iron-limitation imposed on phytoplankton growth (Martin, 1990; Shoenfelt et al., 2018) has been shown to have led to increased carbon export and $\mathrm{CO}_{2, \text { atm }}$ drawdown during the last peak glacial (Kumar et al., 1995; Ziegler et al., 2013; Anderson et al., 2014a; Lamy et al., 2014; Martínez-García et al., 2014; Gottschalk et al., 2016b; Jaccard et al., 
2016). These biological and hydrographic conditions were suggested to have relaxed over the last deglaciation and during Antarctic warming intervals, reducing the biological export of carbon to the deep ocean, and exposing the deep-ocean carbon reservoir to the atmosphere through enhanced vertical mixing and air-sea gas exchange in the Southern Ocean, causing a rise of $\mathrm{CO}_{2, \text { atm }}$ (e.g., Anderson et al., 2009; Skinner et al., 2010, 2014; Gottschalk et al., 2016b; Jaccard et al., 2016; Ronge et al., 2016; Sikes et al., 2016; Basak et al., 2018). In addition, these processes are thought to be closely connected to North Atlantic climate and parallel perturbations in the AMOC (Sigman et al., 2007; Anderson and Carr, 2010; Charles et al., 2010; Denton et al., 2010; Lee et al., 2011; Chiang et al., 2018). Specifically, $\mathrm{CO}_{2}$ evasion from the Southern Ocean may have been promoted through a poleward shift and/or intensifications of the southern-hemisphere westerlies (SHW) and an associated increase in Ekman pumping (Toggweiler et al., 2006; Anderson et al., 2009; Denton et al., 2010; Lee et al., 2011), surface buoyancy variations in the Southern Ocean (Watson and Naveira Garabato, 2006; Watson et al., 2015), Antarctic sea ice retreat and/or the rejuvenation of Southern Ocean deep waters (Skinner et al., 2010 , i.e., a "bi-polar ventilation seesaw"; 2014). These scenarios highlight separate atmospheric and oceanic pathways (though not mutually exclusive), by which northern-hemisphere climate variability might affect the respired carbon budgets and marine carbon cycling in the Southern Ocean. Their relative contributions to $\mathrm{CO}_{2, \text { atm }}$ change remain, however, unclear.

An important test of the classical view of a primary role of Southern Ocean processes in driving millennial-scale $\mathrm{CO}_{2, \text { atm }}$ variations and their connection to North Atlantic climate anomalies gained from proxy records of the last $70 \mathrm{kyr}$ can be made by extending the analyses to older millennial-scale climate events. The penultimate glacial period, i.e., Marine Isotope Stage (MIS) 6, may prove particularly useful for this undertaking, because MIS 6 was characterised by slightly different climatic conditions compared to the last glacial period (i.e., MIS 3), in particular with respect to the extent of northern-hemisphere ice sheets (Svendsen et al., 2004) and the strength of the hydrological cycle (Margari et al., 2010). These differences have likely led to a weaker AMOC during MIS 6 that may be associated with lower-amplitude changes in Antarctic temperature (Margari et al., 2010). We hypothesize that the sensitivity of the ocean carbon system to perturbations was likely different during both glacial periods, and a comparison between the two may therefore provide important insights into the dependency of respired carbon changes in the deep South Atlantic and $\mathrm{CO}_{2, \text { atm }}$ variations to the nature, timing and duration of North Atlantic climate events and overall glacial conditions.

Here, we assess and compare changes in respired carbon content in the Atlantic sector of the Southern Ocean and the AMOC 'geometry' during the last two glacial periods based on sub-Antarctic Atlantic sediment cores MD07-3076Q (14.20 ${ }^{\circ} \mathrm{W}, 44.10^{\circ} \mathrm{S}, 3777 \mathrm{~m}$ water depth) and MD07-3077 $\left(14.23^{\circ} \mathrm{W}\right.$, $44.15^{\circ} \mathrm{S}, 3776 \mathrm{~m}$ water depth). Respired carbon changes are derived from qualitative and quantitative estimates of bottom water oxygen concentrations $\left(\left[\mathrm{O}_{2}\right]\right)$ variations, which are reflected in the enrich- 
ment of redox-sensitive elements in foraminiferal authigenic coatings and epibenthic-to-deep infaunal foraminiferal $\delta^{13} \mathrm{C}$ gradients. Reconstructions of AMOC changes are based on partial sedimentary dissolution proxies that track variations in bottom water carbonate ion saturation. These proxies are sensitive to the presence of northern-sourced (oversaturated) and southern-sourced (undersaturated) water masses, as well as water mass end-member changes, at our study site (Gottschalk et al., 2015a). Additional analyses of past changes in local productivity approximated by determinations of the sedimentary opal content (e.g., Anderson et al., 2014a) and cryosphere dynamics based on the abundance of ice-rafted debris (IRD; e.g., Kanfoush et al., 2000; Nielsen et al., 2007) help to assess the roles of ocean biology and sea ice/icebergs in Southern Ocean carbon cycle dynamics, respectively.

\section{Study area}

Sediment cores MD07-3076Q and MD07-3077 were retrieved from the eastern flank of the MidAtlantic Ocean Ridge and are located within the sub-Antarctic Zone of the Atlantic sector of the Southern Ocean (Fig. 1). The cores were collected at the same site using different coring techniques, i.e., by square kasten- and piston coring, respectively. With a length of $10.9 \mathrm{~m}, \mathrm{MD} 07-3076 \mathrm{Q}$ covers the last $100 \mathrm{kyr}$, while its sister core MD07-3077 has a length of $49.5 \mathrm{~m}$ and extends back to $450 \mathrm{kyr}$ before present (BP) (Vázquez Riveiros et al., 2010). Analyses for MIS 3 are therefore based on core MD07-3076Q, while those for MIS 6 are based on MD07-3077.

The core sites are currently bathed in Lower Circumpolar Deep Water (LCDW), which is a mixture of DIC-rich and $\left[\mathrm{CO}_{3}{ }^{2-}\right]$-low Antarctic Bottom Water (AABW), derivatives of DIC-rich and low- $\left[\mathrm{CO}_{3}{ }^{2-}\right]$ Indian and Pacific Deep Water and DIC-low and high- $\left[\mathrm{CO}_{3}{ }^{2-}\right]$ North Atlantic Deep Water (NADW) (Carter et al., 2009; Talley, 2013). Our site is characterised by slight carbonate (i.e. calcite) oversaturation $\left(\Omega=\left[\mathrm{CO}_{3}{ }^{2-}\right]_{\text {in-situ }} /\left[\mathrm{CO}_{3}{ }^{2-}\right]_{\text {saturated }}=1.09\right)$, but is proximal to carbonate-undersaturated water masses located deeper in the South Atlantic water column. It is therefore sensitive to changes in the preponderance of high- $\left[\mathrm{CO}_{3}{ }^{2-}\right] \mathrm{NADW}$ and low- $\left[\mathrm{CO}_{3}{ }^{2-}\right] \mathrm{AABW}$ in the deep South Atlantic through associated changes in carbonate saturation at the core site (Gottschalk et al., 2015a). The modern $\left[\mathrm{O}_{2}\right]$ at our core site is $215 \mu \mathrm{mol} \mathrm{kg}{ }^{-1}$ (Garcia et al., 2010).

\section{Methods}

\subsection{Respired carbon levels}

Respired carbon levels are directly linked to apparent oxygenation utilization (AOU) in the ocean, which reflects the drawdown of $\mathrm{O}_{2}$ due to the respiration of organic matter (Kroopnick, 1985; Jaccard et al., 2014; Galbraith and Jaccard, 2015). AOU changes were suggested to be the main driver of deepocean $\left[\mathrm{O}_{2}\right]$ changes, because $\left[\mathrm{O}_{2}\right]$ saturation in the surface- and deep ocean varied little over glacialinterglacial timescales (Jaccard and Galbraith, 2012; Galbraith and Jaccard, 2015). We therefore reconstruct bottom water $\left[\mathrm{O}_{2}\right]$ to assess respired carbon changes during the last two glacial periods using 
the two following independent approaches in order to circumvent potential limitations and biases that may come with the analysis of a single proxy.

\subsubsection{Uranium enrichment in foraminiferal coatings}

The enrichment of uranium (U) in marine sediments is mainly a result of reducing conditions in pore waters of marine sub-surficial sediments (Anderson et al., 1989; Barnes and Cochran, 1990; Klinkhammer and Palmer, 1991; Morford and Emerson, 1999; McManus et al., 2006; Tribovillard et al., 2006). Most of the soluble uranyl $\left(\mathrm{U}^{\mathrm{VI}}\right)$ carbonate ions that are reduced to insoluble uraninite $\left(\mathrm{U}^{\mathrm{IV}}\right.$ or $\mathrm{U}^{\mathrm{III}}$ ) under oxygen-depleted conditions in pore waters diffuse from the water column into the sediment (Barnes and Cochran, 1990; Klinkhammer and Palmer, 1991; Morford and Emerson, 1999; Zheng et al., 2002). Uraninite precipitates on any substrate within marine sediments, including detrital material and carbonate shells of foraminiferal tests, resulting in a co-variation of authigenic U levels of bulk sediments and foraminiferal coatings (Boiteau et al., 2012; Chen et al., 2017).

Owing to the very low $\mathrm{U}$ concentrations within the carbonate lattice of foraminiferal shells $(<\sim 20$ nmol mol ${ }^{-1}$ ) (Russell et al., 2004; Yu and Elderfield, 2007; Yu et al., 2008; Raitzsch et al., 2011) compared to those measured on non-reductively cleaned bulk (carbonate lattice and authigenic coating) foraminiferal shells (up to $700 \mathrm{nmol} \mathrm{mol}{ }^{-1}$ ) (Boiteau et al., 2012; Gottschalk et al., 2016b; Lear et al., 2016), the U/Ca ratio of bulk foraminifera obtained by inductively coupled plasma-mass spectrometry (ICP-MS) are dominated by U/Ca ratios of authigenic coatings. As the thickness of the shells and the size of the foraminifera may have varied over time (Barker and Elderfield, 2002) and may have had an impact on foraminiferal $\mathrm{U} / \mathrm{Ca}$ ratios, it was suggested that normalization to manganese (Mn) might alleviate morphological biases (Gottschalk et al., 2016b). Under oxic conditions, Mn(II) is oxidised and precipitates as insoluble Mn(IV) or Mn(III) oxyhydroxides (Calvert and Pedersen, 1996). Under reducing conditions, these $\mathrm{Mn}$ oxides dissolve releasing $\mathrm{Mn}$ (II) that may be precipitated as Mncarbonates below the anoxic boundary, or diffuse upward to the oxic zone, where it can be recycled (Froelich et al., 1979; Tribovillard et al., 2006). As foraminiferal tests in marine sediments act as a nucleus for the accumulation of both solid U- and Mn-phases, they were found to accumulate as in coatings inside and/or outside of the foraminiferal shell (Pena et al., 2005, 2008; Hasenfratz et al., 2016; Detlef et al., 2019). Foraminiferal U/Mn ratios, along with U/Ca ratios (Boiteau et al., 2012), were hence suggested to be sensitive to and indicative of changes in bottom water oxygenation in marine sediments (Gottschalk et al., 2016b; Chen et al., 2017; Detlef et al., 2019).

However, Chen et al. (2017) do not find a close relationship between core-top epibenthic foraminiferal $\mathrm{U} / \mathrm{Mn}$ ratios and bottom water $\left[\mathrm{O}_{2}\right]$. This may not be surprising, because the redox-cycling of $\mathrm{U}$ was suggested to be closely linked to that of Fe (Barnes and Cochran, 1990; Zheng et al., 2002), and hence occurs a few centimeters below the sediment-water interface, and may thus not be recorded by core- 
top foraminifera. This becomes evident in the tandem analyses of planktonic foraminiferal coatings and pore-waters in multi-cores from a well-oxygenated setting performed by Skinner et al. (2019), which show that foraminiferal $\mathrm{Mn} / \mathrm{Ca}$ ratios track the pore-water $\mathrm{Mn}^{2+}$ concentration (with enrichment of both below the anoxic boundary), while foraminiferal $\mathrm{U} / \mathrm{Ca}$ ratios track the loss of $\mathrm{U}$ from porewaters through precipitation of U-compounds in oxygen-depleted sub-surface sediments (slightly lower than the zone of Mn accumulation). These findings emphasise a separation of early diagenetic reactions involving $\mathrm{U}$ and $\mathrm{Mn}$ in sub-surface sediments (Froelich et al., 1979). This is consistent with findings of Detlef et al. (2019), who observe a correlation of foraminiferal U/Ca and $\mathrm{Mn} / \mathrm{Ca}$ ratios in the Bering Sea, suggesting the accumulation of $\mathrm{Mn}$ in authigenic or recrystallized carbonate phases in foraminiferal coatings, possibly under anoxic conditions. The authors suggest that the increase in $U$ accumulation over Mn accumulation in foraminiferal coatings in this setting is proportional to diagenetic alteration, and hence possibly dependent on bottom water $\left[\mathrm{O}_{2}\right]$ conditions. In contrast, Boiteau et al. (2012) show an anticorrelation of foraminiferal $\mathrm{U} / \mathrm{Ca}$ and $\mathrm{Mn} / \mathrm{Ca}$ in foraminiferal samples from the Southeast Atlantic, emphasising different oxic and anoxic pathways of diagenetic precipitation of solid $\mathrm{U}$ - and Mn-phases. Further investigation is needed to fully understand the mechanisms driving the U/Mn proxy. Nonetheless, despite the different processes driving U- and Mn precipitation on foraminiferal shell, there is a strong connection to redox-chemical cycling in sub-marine sediments that is in turn tightly coupled to the availability of oxygen in bottom waters (Boiteau et al., 2012; Gottschalk et al., 2016b; Chen et al., 2017; Detlef et al., 2019; Skinner et al., 2019). In our study, we analyse the U enrichment in authigenic coatings on several foraminiferal species, and report the associated $\mathrm{U} / \mathrm{Ca}$ and $\mathrm{U} / \mathrm{Mn}$ ratios.

The foraminiferal record of redox-sensitive elements may be influenced by post-depositional deepening of the anoxic boundary, which may cause precipitated $U$ compounds to be oxidised leading to a "burn-down" effect (Zheng et al., 2002; Kasten et al., 2003; McManus et al., 2005). As we find high sedimentation rates of 10 to $15 \mathrm{~cm} \mathrm{kyr}^{-1}$ during MIS 3 and 6, we assume that the observed U/Ca and $\mathrm{U} / \mathrm{Mn}$ ratios represent signals that mostly formed in equilibrium with bottom waters, with little overprints from non-steady state processes. We argue that the temporal offset between our redox-sensitive proxy changes and contemporaneous shifts in other foraminiferal proxies during past glacials is limited to a maximum of 500-1000 yr, assuming that oxygen penetration depths into sub-surface sediments were of the order of $\sim 5-7 \mathrm{~cm}$ or lower during past glacials. This is supported by a good agreement of foraminiferal $\mathrm{U} / \mathrm{Ca}$ and $\mathrm{U} / \mathrm{Mn}$ ratios with other bottom water oxygenation proxies and ventilation age changes over the last glacial cycle at the core site (Gottschalk et al., 2016b; Skinner et al., 2019).

$\mathrm{U} / \mathrm{Ca}-$ and $\mathrm{U} / \mathrm{Mn}$ analyses were performed on the planktonic foraminifer Globigerina bulloides (20-30 specimens; 250-300 $\mu \mathrm{m}$ size fraction) and Globorotalia inflata (20-30 specimens; $>212 \mu \mathrm{m}$ size frac- 
tion) for MIS 6 and Termination (T) II, and on G. bulloides (20-30 specimens; 250-300 $\mu \mathrm{m}$ size fraction) and the benthic foraminifer Uvigerina spp. (5-15 specimens; 250-300 $\mu \mathrm{m}$ size fraction) for MIS 3 and TI. Prior to ICP-MS analyses, the foraminiferal samples were cleaned by clay removal and silicate picking (Barker et al., 2003; Boiteau et al., 2012). The reproducibility of U/Ca and U/Mn ratios of replicate samples is within $30 \mathrm{nmol} \mathrm{mol}^{-1}$ and $0.08 \mathrm{mmol} \mathrm{mol}^{-1}(n=6)(1 \sigma)$, respectively.

\subsubsection{Epibenthic-deep infaunal foraminiferal $\delta^{13} \mathrm{C}$ gradients}

The benthic foraminifer Globobulimina affinis is thought to actively migrate towards the low-oxygen microhabitat near or at the anoxic boundary within marine sub-surface sediments (Geslin et al., 2004), and has therefore a deep infaunal habitat (Corliss and Emerson, 1990; McCorkle et al., 1990). The $\delta^{13} \mathrm{C}$ offset of G. affinis from bottom water (i.e., from the supposedly epibenthic foraminifer Cibicidoides kullenbergi), $\Delta \delta^{13} \mathrm{C}_{C k \text {-Ga }}$, has been proposed to record the depletion of pore water $\delta^{13} \mathrm{C}$ due to organic carbon respiration. This is thought to be controlled by bottom water oxygen diffusion into the sediment that is a function of bottom water $\left[\mathrm{O}_{2}\right]$ itself (McCorkle and Emerson, 1988; McCorkle et al., 1990; Hoogakker et al., 2015).We use the $\Delta \delta^{13} \mathrm{C}$-bottom water $\left[\mathrm{O}_{2}\right]$ calibration of Hoogakker et al. (2015) to obtain quantitative estimates of bottom water $\left[\mathrm{O}_{2}\right]$ at our core sites during the past two glacial periods.

We have performed stable isotopic analyses on $G$. affinis $(G a)$ and $C$. kullenbergi $(C k)$ on one to four specimens of the $>150 \mu \mathrm{m}$ size fraction. The analysed $C k$ specimens refer to the sensu latomorphotype as illustrated in Gottschalk et al. (2016a). The samples were measured on Finnigan $\Delta^{+}$ and Elementar Isoprime mass spectrometers at the LSCE in Gif-sur-Yvette (France). Prior to the analyses, foraminifera were rinsed with methanol, ultrasonicated for $10 \mathrm{~s}$, dried at room temperature, and finally roasted under vacuum at $\sim 380^{\circ} \mathrm{C}$ for $45 \mathrm{~min}$ to remove contaminant organic phases or detritus.

The oxygen and carbon isotopic shell composition is expressed as $\delta^{18} \mathrm{O}$ and $\delta^{13} \mathrm{C}$ in \%o versus Vienna Pee Dee Belemnite (VPDB). VPDB is defined with respect to the National Bureau of Standards (NBS)-19 calcite standard $\left(\delta^{18} \mathrm{O}=-2.20 \%\right.$ and $\delta^{13} \mathrm{C}=+1.95 \%$ ) (Coplen, 1988). The mean external reproducibility of our carbonate standards is $\sigma=0.05 \%$ o $\left(\delta^{18} \mathrm{O}\right)$ and $\sigma=0.03 \%\left(\delta^{13} \mathrm{C}\right)$, and the measured NBS-18 $\delta^{18} \mathrm{O}$ and $\delta^{13} \mathrm{C}$ values are $-23.2 \pm 0.2 \%$ VPDB and $-5.0 \pm 0.1 \%$ VPDB, respectively.

\subsection{Deep South Atlantic carbonate ion saturation as an indicator of the Atlantic overturning} 'geometry'

Partial sedimentary dissolution proxies, such as the benthic-to-planktonic $(\mathrm{Be} / \mathrm{Pl})$ foraminiferal ratio, planktonic foraminifer abundances or the planktonic foraminiferal fragmentation, are sensitive to the carbonate saturation (i.e., corrosiveness) of deep South Atlantic bottom waters (Barker and Diz, 2014; Gottschalk et al., 2015a, 2018). We have normalised and averaged these three proxy records from our 
study sites for each glacial period in order to obtain the 'carbonate saturation index' (Gottschalk et al., 2015a). This index qualitatively reflects changes in carbonate saturation at our study site, which is mainly driven by the southward advance of high- $\left[\mathrm{CO}_{3}{ }^{2-}\right]$ NADW (Gottschalk et al., 2015a). However, given nonlinearities of processes affecting this proxy (such as changes in water mass end-members, local sedimentation rate and sediment porosity) it does not reflect changes in the strength of the AMOC, in particular during different time intervals.

$\mathrm{Be} / \mathrm{Pl}$ ratios, planktonic foraminifer abundances and the foraminifer fragmentation were determined by sedimentary census counts of a sample aliquot of the $>150 \mu \mathrm{m}$-fraction (CLIMAP project members, 1984). At least 300 planktonic foraminifera were counted for each sample, which also allowed an estimation of sea surface temperature (SST) changes at the core site based on planktonic foraminiferal assemblages and the Southern Ocean calibration of Haddam et al. (2016). The abundance of planktonic foraminifera is expressed as number per gram dry bulk sediment $(>150 \mu \mathrm{m})$, while the fragmentation represents the percent fraction of planktonic foraminifer fragments (when larger than half a broken shell) of the total abundance of planktonic foraminifera and fragments. The reproducibility of reported planktonic foraminifer abundances, planktonic foraminifer fragmentation and the $\mathrm{Be} / \mathrm{Pl}$ ratio has been inferred from 15 duplicate counts, and amounts to $(1 \sigma=) 6000 \mathrm{~g}^{-1}, 1.9 \%$ and 0.014 , respectively.

\subsection{Opal as an indicator for export production}

The sedimentary biogenic silica (opal) content in our study cores was quantified by Fourier Transform Infrared Spectroscopy (FTIRS; Vogel et al., 2016) using a Vertex 70 FTIR-spectrometer (Bruker Optics Inc.) at the University of Bern. Repeating the analyses of parts of the record in MIS 3 and MIS 6 indicate the robustness of relative changes in sedimentary opal. However, absolute values may differ from wet-chemical opal analyses during MIS 3 (Gottschalk et al., 2016b) and by $4.5 \pm 1.6 \%(n=55)$ across different FTIRS sample batches during MIS 6 (Supplementary Fig. S1). This may be associated with a bias related to increased water content of marine samples on FTIR spectra (Vogel et al., 2016) that we were not able to eliminate entirely from the samples despite several precautionary measures. Because absorbed water in the samples biases the opal content towards higher values, we have corrected all individual datasets onto those opal records with the lowest absolute values (based on calculated offsets in overlapping sections, Supplementary Fig. S1).

\subsection{Ice-rafted detritus as an indicator of sea ice and/or iceberg export}

The abundance of IRD was assessed alongside the census counts of fragmented shells and planktonic and benthic foraminifera (see section 3.2. above). It is reported as percentage with respect to the total number of sediment grains (including foraminifera and fragments). The reproducibility of estimated IRD percentages is within $1.5 \%(1 \sigma, n=15)$. 


\subsection{Chronology}

298

299

300

301

302

303

304

305

306

307

308

309

310

311

312

313

314

315

316

317

318

319

320

321

322

323

324

325

326

327

328

329

330

331

332

Chronological control of sediment core MD07-3076Q younger than 27 kyr BP is based on calibrated radiocarbon ages of mono-specific planktonic foraminifera samples, which have been adjusted for variations in surface ocean reservoir ages (Skinner et al., 2010). The age models of cores MD073076Q (i.e., for MIS 3) and MD07-3077 (i.e., for TII and MIS 6) are based on a stratigraphic alignment of abundance peaks of G. bulloides with maxima in Antarctica air-temperature, represented by peaks of the EPICA (European Project for Ice Coring in Antarctica) Dome C (EDC) SD Antarctic icecore record (Jouzel et al., 2007) (Fig. 2). This approach assumes that temperature-sensitive $G$. bulloides abundance variations at our South Atlantic core site and Antarctic air-temperatures (at EDC) co-vary. We therefore take the age model for $>27 \mathrm{kyr}$ BP for our core site from a previous study that used this approach (Channell et al., 2017) with minor revision of three tiepoints during MIS 6 (encircled symbols in Fig. 2a), in order to produce a better match of $G$. bulloides variations with Antarctica air-temperature (The depths of two of these tiepoints (174.6 and $177.4 \mathrm{kyr}$ ) were shifted $20 \mathrm{~cm}$ towards the top of the core, and the tiepoint at $\sim 2490 \mathrm{~cm}$ was shifted by $1 \mathrm{kyr}$ towards older ages). Our simple approach is consistent with another age model approach that has been applied to study millennial-scale variability at our core site based on the first time derivative of EDC $\delta \mathrm{D}$, as demonstrated in Gottschalk et al. (2015a). During Termination II, we use the age control points of Gottschalk et al. (2016a) that are based on an alignment of abundance variations of Neogloboquadrina pachyderma with EDC $\delta D$. Although this age model approach may deviate from one based on G. bulloides abundance variations (cf. Fig. 2), these age uncertainties are not relevant for the objectives of this paper.

Resulting sedimentation rates range between $5 \mathrm{~cm} \mathrm{kyr}^{-1}$ during the last deglaciation and $15 \mathrm{~cm} \mathrm{kyr}^{-1}$ during MIS 3 and MIS 6 (Fig. 2). We apply a $700 \mathrm{yr}$ ad-hoc-error for each of our planktonic abundance-based tiepoints (not considering absolute age uncertainties of the EDC chronology of up to 2400 yr in MIS 3 and $3000 \mathrm{yr}$ in MIS 6), which translates into a relative age uncertainty of $1700 \pm 500 \mathrm{yr}$

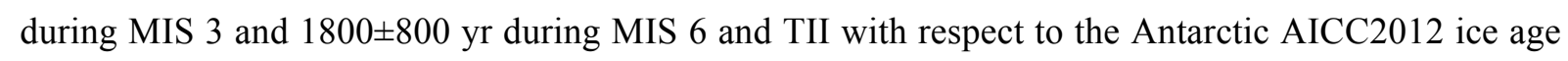
scale (Bazin et al., 2013; Veres et al., 2013). These age uncertainties were estimated based on Monte Carlo simulations with the Bayesian software package Bchron (Haslett and Parnell, 2008), and consider potential sedimentation rate changes in between our selected tiepoints. Although the millennialscale accuracy of our age model is limited, circumstantial support for our age model alignment comes from benthic (Cibicidoides sp.) $\delta^{18} \mathrm{O}$ analyses. During both MIS 3 and MIS 6, we observe a good agreement on millennial time scales between the benthic $\delta^{18} \mathrm{O}$ records at our sub-Antarctic Atlantic site and sediment core MD01-2444 from the Iberian margin in the North Atlantic (Skinner et al., 2007; Fig. 2; $2.6 \mathrm{~km}$ water depth, Margari et al., 2010), although both records are on entirely independent agescales. Benthic $\delta^{18} \mathrm{O}$ records are not per se expected to co-vary in the Atlantic (given the finite timescale of transport/mixing in the ocean, e.g., Skinner and Shackleton, 2005). However, the fact that 
they broadly parallel each other during both glacial intervals lends credibility to our chronostratigraphy.

\subsection{Antarctic ice core $\mathrm{CO}_{2, \text { atm }}$ data}

In order to evaluate the possible influence of changes in deep ocean respired carbon change at our study sites on $\mathrm{CO}_{2, \text { atm }}$, we compare available high-resolution $\mathrm{CO}_{2, \text { atm }}$ records (Bereiter et al., 2015) with our marine proxy data on millennial timescales. The mean temporal resolution of the available ice core $\mathrm{CO}_{2 \text {,atm }}$ data covering MIS $3(\sim 160 \pm 130 \mathrm{yr}, n=279)$ (Bereiter et al., 2012; Ahn and Brook, 2014) is much higher than during MIS $6(\sim 1400 \pm 700 \mathrm{yr}, n=45)$ (Petit et al., 1999; Schneider et al., 2013), rendering a comparison of the $\mathrm{CO}_{2, \text { atm }}$ variability during MIS 6 to our centennially resolved $(220 \pm 70 \mathrm{yr}$, $n=220)$ proxy data problematic. In order to circumvent this potential limitation, millennial-scale $\mathrm{CO}_{2 \text {,atm }}$ variations may be predicted by taking advantage of the tight relationship between the Antarctic temperature proxy $\delta \mathrm{D}$ and $\mathrm{CO}_{2, \text { atm }}$ (Petit et al., 1999; Fischer et al., 2010). We obtain a linear regression between EDC $\delta \mathrm{D}$ (smoothed by a 500 yr-running average; Jouzel et al., 2007) and $\mathrm{CO}_{2, \text { atm }}$ during MIS 3 (63-32 kyr BP) and MIS 6 (184-134.5 kyr BP) using the compilation of Bereiter et al. (2015) (Fig. 3). Our MIS 3 regression shows a correlation coefficient of $\left.R^{2}=0.64\right)(\mathrm{p}<0.05)$, whereas $R^{2}$ for the MIS 6 regression is lower $\left(R^{2}=0.41, \mathrm{p}<0.05\right.$, excluding two outliers; Fig. 3$)$. Both are statistically significant. The resulting $2 \sigma$-uncertainty of the predicted $\mathrm{CO}_{2 \text {,atm }}$ (hereafter referred to as $\mathrm{CO}_{2 \text {,atm-PRED }}$ ) is $10 \mathrm{ppm}$ and $12 \mathrm{ppm}$, respectively (Fig. 3). Given the low resolution of $\mathrm{CO}_{2, \text { atm }}$ data during MIS 6 (Petit et al., 1999; Bereiter et al., 2015), we consider our predicted MIS $6 \mathrm{CO}_{2, \text { atm }}$ data as a reasonable firstorder approximation of true $\mathrm{CO}_{2, \text { atm }}$ variability during that time period. However, high-resolution $\mathrm{CO}_{2, \text { atm }}$ data from Antarctic ice cores during MIS 6 are needed to test the reliability of this approach.

\section{Results}

\subsection{Changes in bottom water oxygenation}

We observe systematic change in the enrichment of uranium in authigenic coatings of foraminifera with past variations in Antarctic temperature and $\mathrm{CO}_{2, \text { atm }}$ (Fig. 4). Bulk foraminifer U/Mn- and U/Ca ratios closely resemble each other both during MIS 3 and MIS 6 (Supplementary Fig. S2). If foraminiferal coating $\mathrm{U}$ and $\mathrm{Mn}$ enrichment is primarily driven by precipitation under anoxic versus oxic conditions (uraninite and Mn-oxides), respectively, bulk foraminifer $\mathrm{U} / \mathrm{Ca}-$ and $\mathrm{Mn} / \mathrm{Ca}$ ratios are expected to anti-correlate (Boiteau et al., 2012). If their enrichment occurs below the anoxic boundary, they are expected to correlate with one another (Detlef et al., 2019; Skinner et al., 2019). U/Ca- and $\mathrm{Mn} / \mathrm{Ca}$ ratios of our planktonic foraminifer samples show a statistically significant positive regression slope (G. bulloides: $n=96$; G. inflata: $n=237$; Supplementary Fig. S2), suggesting that they were governed by similar processes. In contrast, Uvigerina spp. do not show a strong relationship between $\mathrm{U}$ and $\mathrm{Mn}$ enrichment (if at all a slight anti-correlation), potentially highlighting the opposing redoxbehaviour of these two elements. However, irrespective of whether $\mathrm{Mn} / \mathrm{Ca}$ and $\mathrm{U} / \mathrm{Ca}$ are correlated or 
anti-correlated, relative changes in the foraminiferal U/Ca- and U/Mn ratios agree (Supplementary Fig. S2), suggesting that the redox-sensitive $U$ precipitation is the main control of the observed changes in foraminiferal $\mathrm{U} / \mathrm{Ca}$ - and $\mathrm{U} / \mathrm{Mn}$ ratios.

During MIS 3 and TI, G. bulloides and Uvigerina spp. U/Mn ratios and the $\delta^{13} \mathrm{C}_{C k \text {-Ga }}$ gradient show marked variations during strong Antarctic warming events (AIM 8, 12, 14, 16/17), as well as during the more subdued AIM 6 and 7 (sensu EPICA Community Members 2006; Fig. 4, 5). Both bottom

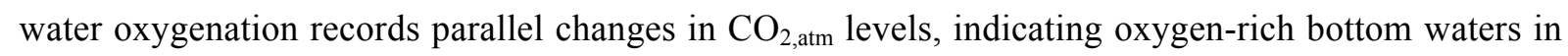
the deep sub-Antarctic Atlantic during rising $\mathrm{CO}_{2, \mathrm{~atm}}$, and vice versa (Fig. 4, 5). The relative change in G. bulloides and Uvigerina spp. U/Mn levels correlates with the magnitude of parallel $\mathrm{CO}_{2, \text { atm }}$ variations (Fig. 6a). During the penultimate glacial period (e.g., AIM 6vi to i), changes in G. inflata U/Mn ratios are similar to Antarctic temperature variations (sensu Margari et al. 2010; Fig. 4, 5). Decreases in G. inflata $\mathrm{U} / \mathrm{Mn}$ levels during Antarctic warming events coincide with predicted increases in $\mathrm{CO}_{2, \mathrm{~atm}}$ during MIS 6 (Fig. 4, 5).

To specify, we estimated the maximum magnitude of foraminiferal U/Mn change during intervals of Antarctic warming as given in Margari et al. (2010) and link that with maximum parallel rise in $\mathrm{CO}_{2, \mathrm{~atm}}$ that we consider to be associated with it (Fig. 5). These intervals do not necessarily fully agree. In fact, during intervals DO14, DO16/17, 6iv and 6ii, the U/Mn maximum occurs slightly later than

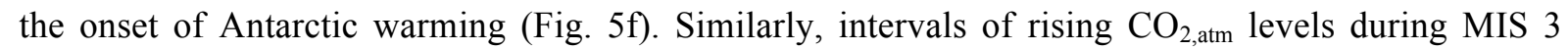
(e.g., DO14 and DO16/17) may last slightly longer than the period of rising temperatures over Antarctica (Fig. 5g). We find that the relationship between the two agrees during both glacial periods (Fig. $6 a)$.

Distinct excursions of $G$. affinis $\delta^{13} \mathrm{C}$ from $C$. kullenbergi $\delta^{13} \mathrm{C}$ during MIS 3 (Supplementary Fig. S3) indicate that bottom water $\left[\mathrm{O}_{2}\right]$ change in parallel with variations in foraminiferal $\mathrm{U} / \mathrm{Mn}$ amounts to $110 \pm 50 \mu \mathrm{mol} \mathrm{kg}^{-1}$ on average (Fig. 4; Gottschalk et al., 2016b). Although the U/Mn proxy seems to provide the most consistent pattern of variability between the two glacials, its agreement with $\Delta \delta^{13} \mathrm{C}_{C k}$ ${ }_{G a}$-based bottom water $\left[\mathrm{O}_{2}\right]$ variations is poor (Fig. 4). As the $\Delta \delta^{13} \mathrm{C}_{C k \text {-Ga }}$ proxy is based on the aerobic respiration of organic matter in marine sub-surface sediments, one can surmise that strong carbon fluxes to the sea floor may have caused anaerobic organic matter degradation in sub-surface sediments to severely bias the proxy. This might have been the case during MIS 6, but not during MIS 3. Furthermore, the $\Delta \delta^{13} C_{C k-G a}$ proxy relies on an accurate representation of pore-water $\delta^{13} \mathrm{C}$ at the anoxic boundary in sub-surface sediments via the deep-infaunal benthic foraminifera G. affinis, and of bottom water $\delta^{13} \mathrm{C}$ levels in bottom waters by the benthic foraminifer $C$. kullenbergi. Either or both of these conditions might not have been met during MIS 6: firstly, Globobulimina species and other deep infaunal benthic foraminifera were shown to be capable of denitrification, and can hence thrive signifi- 
cantly below the anoxic boundary, where pore water $\delta^{13} \mathrm{C}$ is reduced independently of $\left[\mathrm{O}_{2}\right]$ (RisgaardPetersen et al., 2006; Piña-Ochoa et al., 2010; Glock et al., 2019); and secondly, C. kullenbergi was suggested to thrive and possibly prefer slightly infaunal habitats with lower $\delta^{13} \mathrm{C}$ than in bottom waters (Gottschalk et al., 2016a). Along with large intra-species $\delta^{13} \mathrm{C}$ variability and potential vital effects of both benthic foraminifer species, as well as carbonate dissolution changing the pore-water $\delta^{13} \mathrm{C}$ gradient, these processes may have conspired to cause an insensitivity of the $\Delta \delta^{13} \mathrm{C}$ proxy to bottom water $\left[\mathrm{O}_{2}\right]$ changes during MIS 6 . The discrepancy of our MIS $6 \Delta \delta^{13} \mathrm{C}_{C k-G a}$ data underlines possible differences in glacial climate background conditions but also emphasizes the need for further work investigating the controls on both the $\Delta \delta^{13} \mathrm{C}_{C k-G a}$ and $\mathrm{U} / \mathrm{Mn}$ redox proxies under a wide range of depositional and hydrographic settings.

\subsection{Changes in the carbonate saturation state of the deep sub-Antarctic Atlantic Ocean}

The carbonate saturation index (and all individual partial sedimentary dissolution proxies; Supplementary Fig. S4) exhibits several minima during MIS 3 and MIS 6 that indicate the presence of corrosive bottom waters in the deep sub-Antarctic Atlantic, likely of southern origin (Fig. 5; Gottschalk et al., 2015a). This is also consistent with quantitative bottom water $\left[\mathrm{CO}_{3}{ }^{2-}\right]$ variations at the study site during MIS 3 (Supplementary Fig. S4; Gottschalk et al., 2015a). The saturation index minima are paralleled by gradually decreasing foraminiferal U/Mn ratios (Fig. 5), and coincides with minima in epibenthic foraminiferal $\delta^{13} \mathrm{C}$ at the deep Iberian Margin (Fig. 7; Skinner et al., 2007; Margari et al., 2010). The duration of northern-hemisphere stadials was suggested to be expressed in the length of parallel Antarctic warming (Margari et al., 2010). By construction, SST at the core site closely varies with Antarctic temperature, and we hence compare the duration of Antarctic warming, i.e. the length of northern-hemisphere stadials, with the maximum amplitude of foraminiferal U/Mn change that we consider to be associated with it (Fig. 5; Margari et al., 2010). We find that the magnitude of change in foraminiferal U/Mn ratios during both glacial periods linearly correlates with the duration of northernhemisphere stadial conditions, in a similar fashion (Fig. 6b).

The presence of corrosive bottom waters at our core site (i.e., low saturation indices) also parallels

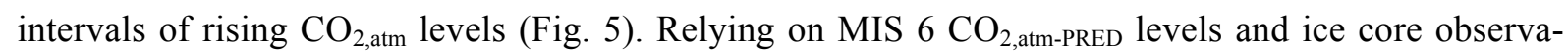
tions during MIS 3 (Bereiter et al., 2015), we observe a good correlation between the duration of these stadials and the magnitude of concomitant $\mathrm{CO}_{2, \text { atm }}$ increase (Fig. 6c). No significant difference in the relationship between the two parameters during MIS 3 and MIS 6 can be identified (Fig. 6c)..

\subsection{Changes in opal percentages}

During MIS 3 and TI, changes in sedimentary opal percentages in MD07-3076Q broadly co-vary with EDC dust fluxes (Fig. 4; Gottschalk et al., 2016b). This relationship could suggest an influence of aeolian dust-driven iron fertilization on nutrient utilization and export production in the sub-Antarctic 
Zone during the last glacial period (Martin, 1990; Anderson et al., 2014b; Lamy et al., 2014; Martínez-

445 García et al., 2014; Gottschalk et al., 2016b). In contrast, during MIS 6 and TII, the link between opal 446 percentages and EDC dust variations is rather poor on millennial timescales, and significant offsets exist between changes in the sedimentary opal content at our study site and the EDC dust flux record (Fig. 4).

\subsection{Ice-rafted debris}

451

452

453

454

455

The abundance of IRD in our study core during the first half of MIS 3 is low but progressively increases towards the end of MIS 3, with pronounced peaks during North Atlantic stadials, and periods of Antarctic warming (Fig. 7). IRD percentages were generally higher during MIS 6 than during MIS 3, and show a more distinct response during stadials (Fig. 7). Kanfoush et al. (2000) interpreted IRD peaks in the South Atlantic as indication of significant iceberg fluxes to the South Atlantic. In contrast, Nielsen et al. (2007) highlighted that a large proportion of the IRD material in the South Atlantic identified by Kanfoush et al. (2000) was likely transported from the South Sandwich and Bouvet Islands via sea ice.

\section{Discussion}

\subsection{Changes in deep South Atlantic carbon sequestration during the last two glacial periods}

Our foraminiferal U/Mn records spanning MIS 3 and MIS 6 indicate increases in bottom water oxygenation in the deep South Atlantic during North Atlantic stadials (only partly supported by the $\Delta \delta^{13} \mathrm{C}_{G a-C k}$ - bottom water [O $\mathrm{O}_{2}$ ] proxy in MIS 6), which indicate changes in the respired carbon content of the deep South Atlantic (Gottschalk et al., 2016b; this study). During MIS 3, these occur in parallel to reductions in the sedimentary opal content, rising SSTs and increased ice-rafting/-export (Fig. 5; Gottschalk et al., 2016b; this study). This also applies to MIS 6, with the exception of distinct offsets between variations in opal, Antarctic dust fluxes and deep South Atlantic bottom water oxygen changes (Fig. 4).

In MIS 3, variations in the degree of iron fertilization via aeolian dust supply were suggested to control export production, and hence opal fluxes, in the sub-Antarctic Atlantic (Anderson et al., 2014a; Martínez-García et al., 2014), contributing to millennial-scale bottom water oxygen and respired carbon changes at depth (Gottschalk et al., 2016b). However, whether the same mechanism operated during MIS 6 remains ambiguous (Fig. 4). The observed offsets may be caused by sediment winnowing or -focussing, or sedimentary opal percentages may in fact poorly represent annually integrated export production (of all taxonomic groups) in the sub-Antarctic Atlantic. Indeed, the opal content in marine sediments was shown to be influenced by the availability of silicic acid, Antarctic sea ice extent, ecosystem structures and the degree of diatom silicification causing variable $\mathrm{Si}$ : C ratios of exported material (Chase et al., 2015). Irrespective of whether our opal in MIS 6 faithfully records export produc- 
tion, we argue based on our proxy records and earlier findings (Gottschalk et al., 2016b) that increased oxygen levels and decreased respired carbon content in the deep South Atlantic during intervals of Antarctic warming did not occur without the contribution from increased ventilation of the deep Southern Ocean (e.g., Skinner et al., 2010, 2014; Gottschalk et al., 2015b, 2016b; Jaccard et al., 2016). Southern Ocean ventilation was likely accompanied by increased air-sea $\mathrm{CO}_{2}$ equilibration and adjusted surface ocean buoyancy forcing in the Antarctic Divergence Zone of the Southern Ocean, driving

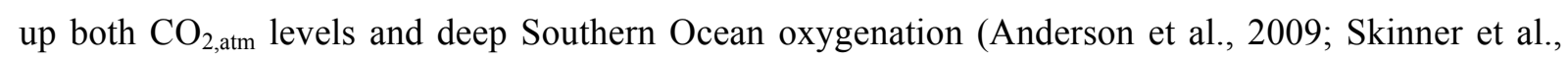
2010, 2014; Gottschalk et al., 2015b, 2016b; Jaccard et al., 2016). These changes have likely also affected deep-ocean respired carbon content in other ocean basins, such as the Atlantic and the Pacific Ocean (e.g., Menviel et al., 2015b, 2018; Umling and Thunell, 2017; Chalk et al., 2019). Hence, we suggest that similar mechanisms of (southern high-latitude) oceanic $\mathrm{CO}_{2}$ release might have operated during the last two glacial period, which is supported by similar patterns of reconstructed bottom water oxygenation change at our study site and parallel $\mathrm{CO}_{2, \text { atm }}$ rise observed and predicted from Antarctic ice core proxy data during MIS 3 and MIS 6, respectively (Fig. 6a). Our results therefore predict much higher variability in $\mathrm{CO}_{2, \text { atm }}$ during MIS 6 than current observations from Antarctic ice cores convey.

The occurrence of saturation index minima in the deep South Atlantic during intervals of increasing bottom water oxygenation (Fig. 6) indicates a shallower cell and/or reduced southward advection of NADW, favouring the presence of southern-sourced (carbonate ion-undersaturated) water masses at our core site, as suggested previously (Gottschalk et al., 2015a). This is supported by an agreement of our saturation index with epibenthic $\delta^{13} \mathrm{C}$ - (Skinner et al., 2007; Margari et al., 2010) and SST changes at the Iberian Margin (Martrat et al., 2007; Fig. 7), the high-resolution ${ }^{231} \mathrm{~Pa} /{ }^{230} \mathrm{Th}$ record from Bermuda Rise (Henry et al., 2016) and a carbonate saturation record from the deep Cape Basin (Gottschalk et al., 2018), which reflect similar AMOC changes in the Atlantic basin. This agreement corroborates a strong causal link between bottom water $\left[\mathrm{O}_{2}\right]$ changes in the deep South Atlantic and end-member changes of southern-sourced water masses related to variations in air-sea gas exchange- and/or the ventilation rate, which may be linked to variations in the southward extent of NADW.

However, this may be challenged by the observation of increasing bottom water oxygenation (i.e., decreasing respired carbon levels) in deep South Atlantic during periods of rising $\mathrm{CO}_{2, \text { atm levels, de- }}$ spite low $\left[\mathrm{CO}_{3}{ }^{2-}\right]$ levels (i.e., saturation index minima) (Fig. 5), whereas a positive correlation between bottom water $\left[\mathrm{CO}_{3}{ }^{2-}\right]$ and -oxygenation is expected. Our saturation index in fact shows an initial drop at the stadial onset and a subsequent gradual increase towards the end of the stadial (Fig. 5). Changes in bottom water $\left[\mathrm{O}_{2}\right]$ and $\left[\mathrm{CO}_{3}{ }^{2-}\right]$ may be affected by different processes operating on different timescales, involving not only changes in the amount of respired carbon, but also changing northern- and southern-sourced end-member signatures and/or -contributions. A decrease in the contribution of northern-sourced water masses might have strongly affected bottom water $\left[\mathrm{CO}_{3}{ }^{2-}\right]$ levels at the onset 
of stadial conditions, when differences in bottom water $\left[\mathrm{O}_{2}\right]$ between northern- and southern-sourced water masses might have been small, thus explaining the absence of abrupt changes in our U/Mnbased bottom water $\left[\mathrm{O}_{2}\right]$ record. During North Atlantic stadials, however, increasing equilibration of southern-sourced water masses with the atmosphere and increased AABW formation might have rapidly affected bottom water $\left[\mathrm{O}_{2}\right]$ but more slowly $\left[\mathrm{CO}_{3}{ }^{2-}\right]$, because the carbonate system has an order of magnitude longer equilibration time as compared to non-dissociating gases. Further analyses are required to test this proposition.

\subsection{Inter-hemispheric climate variability and changes in deep-ocean carbon storage during the} last two glacial periods

The exact mechanisms that connect the hemispheres over deglaciations or millennial-scale climate events, and their implications for ocean respired carbon storage and $\mathrm{CO}_{2 \text {,atm }}$ change, remain difficult to unravel. However, insights into the controls on deep-ocean respired carbon storage in the deep South Atlantic may evolve from a comparison of millennial events occurring under different background climate states during MIS 3 and MIS 6 (sections 5.2.1. and 5.2.2 below) and from a comparison of our proxy data with numerical model outputs (sections 5.2.3. and 5.2.4).

\subsubsection{Role of glacial background conditions}

We observe slightly higher foraminiferal $\mathrm{U} / \mathrm{Mn}$ ratios (indicative of lower $\left[\mathrm{O}_{2}\right]$ and higher respired carbon levels) during MIS 6 (mean U/Mn=1.12 $\mathrm{mmol} \mathrm{mol}^{-1}$, 183-143.5 kyr BP) than during MIS 3 (mean $\mathrm{U} / \mathrm{Mn}=0.75 \mathrm{mmol} \mathrm{mol}^{-1}, 63-32 \mathrm{kyr} \mathrm{BP}$ ) (Fig. 4). This may be associated with differences in the foraminiferal species used for the U/Mn analyses, but a few G. bulloides and Uvigerina spp. analyses during MIS 6 show agreement or slightly higher values than the G. inflata data (Fig. 4), which supports our notion. Although this observation needs to be tested with other proxy data, our data suggests overall more intense respired carbon sequestration in the deep South Atlantic during MIS 6 compared to MIS 3. In contrast, our $\Delta \delta^{13} \mathrm{C}$-derived $\left[\mathrm{O}_{2}\right]$ data suggest similar bottom water oxygenation, and hence respired carbon levels, during these two glacial periods (Fig. 4), but as mentioned above this $\left[\mathrm{O}_{2}\right]$ proxy may be biased during MIS 6 . On the basis of North Atlantic benthic $\delta^{13} \mathrm{C}$ data, Margari et al. (2010) argued for a shallower Atlantic overturning cell during MIS 6 than during MIS 3. This may have promoted an expansion of southern-sourced water masses, and may have hampered mid-depth mixing with overlying (northern-sourced) water masses, more so during MIS 6 than during MIS 3, owing to increased distance from rough topography (Adkins, 2013; Ferrari et al., 2014) or an increased density difference between the two. This slightly different water mass structure in the Atlantic and Southern Oceans during MIS 6 may have caused overall increased carbon sequestration in the deep

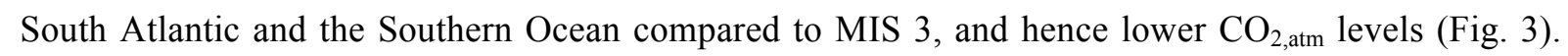
This is supported by numerical model simulations that highlight an increased carbon sequestration 
potential of the ocean through a combined weakening of the overturning rate of both NADW and AABW (Menviel et al., 2017; Ödalen et al., 2018).

In addition, we find increased variability in IRD supply to the central South Atlantic and overall cooler SST conditions during MIS 6 than during MIS 3 (Fig. 7). Our data are consistent with a more proximal seasonal sea ice edge to the study site and/or an increased production of icebergs, which would suggest more extensive sea ice cover and generally colder conditions in the Southern Ocean during MIS 6 (Fig. 7). Along with associated changes in Southern Ocean buoyancy forcing, more extended Antarctic sea ice cover during MIS 6 may have contributed to stronger respired carbon storage during MIS 6 compared to MIS 3, as long as this reduced ocean-to-atmosphere $\mathrm{CO}_{2}$ fluxes (Stephens and Keeling, 2000) more than it reduced atmosphere-to-ocean $\mathrm{CO}_{2}$ fluxes due to diminished biological export production (Kurahashi-Nakamura et al., 2007; Sun and Matsumoto, 2010). Overall, our findings suggest that the difference in glacial boundary conditions, specifically through impacts on water mass geometries in the Atlantic (as indicated by Iberian margin benthic $\delta^{13} \mathrm{C}$ values) and Antarctic surface buoyancy forcing (as shown by IRD abundances at our study site) likely accounted for differences in deep ocean carbon storage and $\mathrm{CO}_{2, \text { atm }}$ background levels during MIS 3 and MIS 6 (Fig. 3).

\subsubsection{Stadial duration and atmospheric $\mathrm{CO}_{2}$ rise}

Intervals of rising bottom water oxygenation, and hence decreasing respired carbon levels in the deep South Atlantic, coincide with periods of weakened AMOC, i.e. stadials, during the last two glacial periods (Fig. 4). The tight relationship between the duration of northern-hemisphere stadials and the magnitude of concomitant bottom water oxygen increase at our core site (Fig. 6b) suggests that respired carbon is gradually lost from the deep South Atlantic during AMOC perturbations. The associated millennial adjustment timescale may reflect the influence of Southern Ocean vertical mixing and deep-ocean turnover rather than fast (centennial-scale) adjustments in the terrestrial biosphere for instance. The observed link between deep South Atlantic oxygen/respired carbon changes and $\mathrm{CO}_{2, \text { atm }}$ variations (Fig. 6c) suggests that the time the AMOC remains suppressed largely defines the net $\mathrm{CO}_{2}$ flux from the ocean to the atmosphere, thus determining the magnitude of $\mathrm{CO}_{2, \text { atm }}$ increase during stadials.

Our interpretation is supported by idealised numerical simulations of stadial periods and parallel $\mathrm{CO}_{2 \text {,atm }}$ change forced by freshwater fluxes to the North Atlantic (see crosses in Fig. 6c; Gottschalk et al., 2019). Although these simulations have different experimental designs, background conditions and forcing functions, the simulated $\mathrm{CO}_{2, \text { atm }}$ change at the end of stadials is broadly consistent with our observations (Fig. 6c; Schmittner and Galbraith, 2008; Bouttes et al., 2012; Gottschalk et al., 2019), and is largely driven by ocean carbon release (albeit from different ocean reservoirs) with compensatory effects from carbon inventory changes in the terrestrial biosphere (e.g., Marchal et al., 1998; 
Schmittner and Galbraith, 2008; Bouttes et al., 2012; Menviel et al., 2014). This emphasises that the observed millennial adjustment timescale of $\mathrm{CO}_{2, \text { atm }}$ in Fig. $6 \mathrm{c}$ is consistent with an influence from deep-ocean ventilation (Schmittner and Galbraith, 2008).

However, during short stadials, rapid changes in the terrestrial biosphere such as the decline of boreal forests and/or the expansion of southern-hemisphere land vegetation may dominate the atmospheric carbon inventory (Köhler et al., 2005; Menviel et al., 2008; Bozbiyik et al., 2011; e.g., Bouttes et al., 2012). This may also be influenced by fast upper-ocean carbon release through SHW strengthening (Menviel et al., 2018) or rapid sea ice changes (Rae et al., 2018). Numerical simulations show that modelled $\mathrm{CO}_{2, \text { atm }}$ change during short stadials ( $<700$ years) may range between slightly positive and negative depending on the interplay between oceanic versus terrestrial processes (Fig. 6c; Gottschalk et al., 2019), while $\mathrm{CO}_{2, \text { atm }}$ changes observed in the Antarctic ice cores BYRD and Siple Dome were suggested to be negligibly small during those intervals (Ahn and Brook, 2014). Two different modes of $\mathrm{CO}_{2, \text { atm }}$ change during stadials may thus be identified: the first dependent on a more sensitive and fast responding terrestrial biosphere or another "reactive" reservoir such as the upper ocean; and the second driven by slowly adjusting ocean processes (i.e., deep-ocean ventilation and -overturning).

The relationship between the duration of an AMOC perturbation (i.e., stadial) and deep South Atlantic respired carbon/oxygen- and $\mathrm{CO}_{2, \text { atm }}$ change is similar during MIS 3 and MIS 6 (Fig. 6b,c). The rate of respired carbon loss from the deep (southern, high-latitude) ocean during northern-hemisphere stadials was hence not discernibly different during MIS 3 and 6 . However, this contrasts with suggested differences in the oceanic settings during the last two glacial periods: It has been suggested that the AMOC was overall weaker during MIS 6, as shown by different baseline benthic $\delta^{13} \mathrm{C}$ values at the Iberian margin during MIS 3 and MIS 6 (Fig.7f; Margari et al., 2010). The generally weaker AMOC of MIS 6 may have resulted from a reduced density of northern-sourced water masses owing to a stronger hydrological cycle in the mid-latitude North Atlantic (Margari et al., 2010). Furthermore, the change in Antarctic temperature and in SST at our core site (Fig. 7b) is much smaller in MIS 6 for a given stadial duration than in MIS 3 (Margari et al., 2010), and may suggest weaker AMOC perturbations and less intense Southern Ocean upwelling and deep-ocean ventilation during MIS 6. Additionally, increased IRD abundances at our study site during North Atlantic stadials in MIS 6 imply stronger ice wasting and/or -export during periods of Antarctic warming, when compared to MIS 3, which could have had implications for the density structure of the Southern Ocean surface, and hence ocean-atmosphere $\mathrm{CO}_{2}$ fluxes during MIS 3 and MIS 6. However, despite these dynamic and hydrographic differences, we do not resolve any systematic differences in respired carbon loss from the deep sub-Antarctic Atlantic and associated $\mathrm{CO}_{2, \text { atm }}$ change during the last two glacial periods. Although uncertainties of our estimates are large, in particular with respect to $\mathrm{CO}_{2, \text { atm }}$ change during MIS 6, this suggests that the rate of Southern Ocean $\mathrm{CO}_{2}$ outgassing is similar during northern-hemisphere stadials of the last two glacial 
periods (Fig. 7). However, the degree to which compensatory effects in MIS 6, such as when a larger respired deep-ocean carbon pool and weaker AMOC/Southern Ocean perturbations are combined, cause a similar $\mathrm{CO}_{2, \text { atm }}$ rate of change as in MIS 3 remains unconstrained.

\subsubsection{Comparison with equilibrium climate model simulations}

Numerical simulations forced by freshwater hosing in the North Atlantic produce a weakened AMOCscenario (i.e., stadial conditions) that is qualitatively consistent with our observations (Gottschalk et al., 2019). A subset of these freshwater hosing experiments find that changes in Southern Ocean vertical mixing and -carbon release during AMOC perturbations are the main driver of simulated ocean carbon loss and increase in $\mathrm{CO}_{2, \text { atm }}$ at that time (Schmittner et al., 2007; Schmittner and Galbraith, 2008; Schmittner and Lund, 2015). This is supported by Menviel et al. (2008, 2014, 2015a, 2015b, 2018), who highlight that an agreement of simulated and observed $\mathrm{CO}_{2, \text { atm }}$ changes during stadial periods can only be achieved through an increase in AABW formation and Southern Ocean convection. Our proxy data support these model findings and highlight the operation of a bipolar seesaw in deep ocean convection between the northern and southern hemispheres ("ventilation seesaw") during the last two glacial periods, which extends the findings of Skinner et al. (2014) to the last two glacial periods.

Intensifications and/or poleward shifts of the SHW were also suggested to occur in parallel with AMOC perturbations and to increase ocean ventilation and ocean-to-atmosphere $\mathrm{CO}_{2}$ fluxes, with implications for $\mathrm{CO}_{2, \text { atm }}$ (Anderson et al., 2009; Lee et al., 2011; Jaccard et al., 2016; Chiang et al., 2018; Pedro et al., 2018). This can be assessed based on numerical simulations that are forced by changes in the SHW, taking advantage of the recent compilation of Gottschalk et al. (2019).

Model simulations forced by increases in the $\mathrm{SHW}$ wind intensity show a $\mathrm{CO}_{2, \text { atm }}$ rise owing to enhanced Ekman pumping and ocean carbon loss primarily, but not exclusively, from intermediate depths ( 500-2000 m) (Gottschalk et al., 2019). These simulations would be consistent with our observations, if ocean carbon loss from the deep South Atlantic was non-negligible. With the exception of model simulations of Völker and Köhler (2013), numerical models forced by southward shifts of the SHW show a reduction in the surface outcrop area of deep water masses in the Southern Ocean, which decreases the ocean-atmosphere $\mathrm{CO}_{2}$ flux and therefore lowers $\mathrm{CO}_{2, \text { atm }}$ levels (Gottschalk et al., 2019). These simulations predict increased deep-ocean carbon storage in the South Atlantic during North Atlantic stadials, and would hence contradict our findings.

In summary, while equilibrium model simulations support our proxy data-based interpretation of an

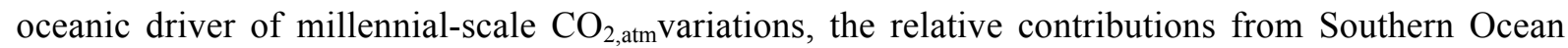


vertical mixing and/or wind-driven Ekman pumping, both potentially representing a Southern Ocean response to North Atlantic climate anomalies (e.g., Anderson and Carr, 2010), cannot be unraveled.

\subsubsection{Comparison with transient model simulations}

To gain more insights into the possible drivers of our deep South Atlantic respired carbon changes, we compare our proxy data with recent transient model simulations of the last early deglaciation (H1) performed with LOVECLIM, an Earth system model of intermediate complexity (Menviel et al., 2018). These simulations test the influence of a shutdown of the $\mathrm{AMOC}$ on $\mathrm{CO}_{2, \text { atm }}$ levels (Fig. 8; Menviel et al., 2018) through freshwater supply to the North Atlantic (0.04-0.07 Sv, 19 to $16.2 \mathrm{kyr})$ and to the Southern Ocean (0.1 Sv, 19 to $15 \mathrm{kyr}$ ), as well as a 20\%-weakening of the SHW (simulation 'LH1'). They also analyse the influence of a surface buoyancy-driven and wind-driven increase in Southern Ocean convection stimulated through additionally prescribing salt fluxes in the Southern Ocean (simulation 'LH1-SO'; -1.5 Sv, 18-18 kyr) or intensifications of the SHW wind stress (simulation 'LH1-SHW'; 20\%-increase, 18.3 to $15 \mathrm{kyr}$ ). Simulation 'LH1-SO-SHW' combines changes in surface buoyancy and winds and applies both a SHW intensification and negative Southern Ocean freshwater fluxes.

We derive depth-varying $\mathrm{O}_{2}$ ]- and DIC anomalies for $\mathrm{H} 1$ for the South Atlantic $\left(60^{\circ} \mathrm{W}-20^{\circ} \mathrm{E}, 40\right.$ $\left.70^{\circ} \mathrm{S}\right)$ - and the Southern Ocean $\left(40-70^{\circ} \mathrm{S}\right)$ for each of these simulations by referencing the simulated water column profiles from model year $15 \mathrm{ka}$ to background levels at model year $18 \mathrm{ka}$ (Fig. 8a,b), and compare transient changes with our South Atlantic proxy data (Fig. 8c). The simulations show a 3 kyr-period of AMOC suppression, which is at the upper end of stadial durations considered here (Fig. $6 c)$. Although these simulations apply transient changes in the orbital parameters and northernhemisphere ice sheet evolution that are appropriate for $\mathrm{H} 1$, we assume that the model results provide insights into the dynamics during other North Atlantic stadial periods.

Simulations LH1-SO and LH1-SO-SHW are characterised by increased AABW formation, and the upwelling of $\mathrm{CO}_{2}$-rich $\mathrm{CDW}$, which leads to a carbon loss from the deep ocean, both from the Southern and Pacific Oceans, and a simulated $\mathrm{CO}_{2, \text { atm }}$ rise of 10-20 ppm (see Fig. 3 in Menviel et al., 2018). These findings are qualitatively consistent with our interpretation of the proxy data, although there are offsets in absolute bottom water $\left[\mathrm{O}_{2}\right]$ anomalies between the model and proxy data (Fig. 8a,b). However, transient changes in simulated bottom water $\left[\mathrm{O}_{2}\right]$ in the South Atlantic closely resemble those observed in our proxy analyses (Fig. 8c), and is hence consistent with a loss of (respired) carbon from the South Atlantic (Fig. 8d).

In simulation LH1, Southern Ocean convection is suppressed due to parallel freshwater hosing in the Southern Ocean and weakened SHW winds (Menviel et al., 2018). This leads to little change in simu- 
lated $\mathrm{CO}_{2 \text {,atm }}$ levels owing to a balance between increased ventilation and release of carbon from North Pacific intermediate depths and increased Atlantic carbon storage (Menviel et al., 2018). This is at odds with our proxy data and observed $\mathrm{CO}_{2 \text {,atm }}$ change during long stadials (Fig. 8). In the SHWdriven simulation, LH1-SHW simulated $\mathrm{CO}_{2, \text { atm }}$ increases on a centennial timescale, because upper Southern Ocean convection increases and oceanic carbon is rapidly lost primarily from the upper and intermediate ocean (Menviel et al., 2018). Its impact on simulated deep-ocean $\left[\mathrm{O}_{2}\right]$ and DIC was however minimal compared to what our observations suggest (Fig. 8). Although our deep-ocean proxy data cannot rule out a SHW-driven mechanism, they suggest that changes in the SHW geometry have likely not operated alone to change $\mathrm{CO}_{2, \text { atm }}$.

Overall, simulated geochemical anomalies in the South Atlantic and the Southern Ocean strongly resemble each other (Fig. 8), which suggests that our deep South Atlantic core site may be representative of a wider region of the Southern Ocean. Our proxy data comparison with the transient simulations of Menviel et al. (2018) corroborates our proxy interpretations of a role of Southern Ocean vertical mixing in changes of deep-ocean respired carbon storage, and hence millennial-scale $\mathrm{CO}_{2 \text {,atm }}$ variations, during North Atlantic stadials.

717

\section{Conclusion}

We extend existing high-resolution proxy reconstruction of deep South Atlantic bottom water oxygen changes, and by inference variations in respired carbon content, from the last glacial period to MIS 6 . Mainly based on sedimentary redox-proxies, we show that during both glacial periods respired carbon levels in the deep South Atlantic changed in parallel with millennial-scale $\mathrm{CO}_{2, \text { atm }}$ variations. Our observations support earlier findings of a contribution of increased Southern Ocean convection and ocean-to-atmosphere $\mathrm{CO}_{2}$ fluxes in the Southern Ocean to increases in millennial-scale $\mathrm{CO}_{2 \text {,atm }}$ concentrations, assuming a large enough area of the ocean was similarly affected and the associated marine carbon loss was not fully compensated by terrestrial carbon uptake.

Our foraminiferal $\mathrm{U} / \mathrm{Mn}$ data suggest that respired carbon storage was overall slightly larger during MIS 6 than during MIS 3 in the deep South Atlantic, possibly due to more expansive southern-sourced water masses and a shallower AMOC cell, more expansive Antarctic sea ice cover and overall colder conditions in the Southern Ocean. These glacial differences may have accounted for overall slightly lower observed $\mathrm{CO}_{2, \text { atm }}$ levels during MIS 6 than during MIS 3. Our findings suggest that glacial background climate conditions have an impact on marine carbon cycling in the Southern Ocean, for instance by influencing the extent of Antarctic sea ice (and hence, surface ocean buoyancy forcing in the Southern Ocean). 
Our proxy data highlight that the magnitude of carbon release from the Southern Ocean was proportional to the duration of the AMOC perturbation. This suggests that the rate of $\mathrm{CO}_{2, \text { atm }}$ hange during long stadial periods was broadly constant, and was primarily set by the millennial timescale for deep ocean adjustment (i.e., ocean mixing/ventilation, Southern Ocean-atmosphere $\mathrm{CO}_{2}$ fluxes). During long stadials, likely reflecting strong AMOC perturbations, the duration of the weakened AMOC may have therefore primarily determined the magnitude of net ocean carbon release, and hence the $\mathrm{CO}_{2, \text { atm }}$ rise. However, for shorter stadial periods, processes operating on centennial timescales such as adjustments of land carbon inventories, with contributions from SHW- or sea ice effects on Southern Ocean upper-ocean convection and $\mathrm{CO}_{2}$ outgassing, may have influenced $\mathrm{CO}_{2, \text { atm }}$ levels, because they would have overwhelmed the effects of much slower deep-ocean overturning.

Based on our proxy data and a comparison with existing numerical model simulations, we cannot discriminate between possible oceanic and atmospheric mechanisms driving a teleconnection between Southern Ocean carbon dynamics and North Atlantic climate anomalies, but contributions from both seem likely. A comparison with recent transient model simulations performed with LOVECLIM (Menviel et al., 2018) show the closest model-data agreement for scenarios with increased Southern Ocean convection prescribed through Southern Ocean salt fluxes at the surface, rather than SHW-only scenarios. However, whether the prescribed changes in Southern Ocean surface buoyancy forcing are realistic and how they are mechanistically linked to North Atlantic climate anomalies remains yet elusive and needs further study. A better understanding of the atmospheric and oceanic mechanisms by which interhemispheric climate variability affect the Southern Ocean carbon cycle and $\mathrm{CO}_{2, \text { atm }}$ (for instance through buoyancy-driven Southern Ocean vertical mixing, SHW-driven Ekman pumping, and/or Antarctic sea ice extent) may ultimately emerge from tandem reconstructions of respired carbon reconstruction at intermediate and deep sites throughout the global ocean, and through comparison with existing and evolving climate model simulations.

\section{Acknowledgements}

This study was supported by the Gates Cambridge Trust, the German Research Foundation (through grant GO 2294/2-1 to J.G.), the Royal Society, NERC grant NE/J010545/1, the Cambridge Newton Trust (L.C.S.), the Swiss National Science Foundation (grants PP00P2_144811 and 200021_163003 toS.L.J.), the Australian Research Council (grant DE150100107 to L.M.), and the European Research Concil (grant 339108 to C.W.). We thank Jinhwa Shin and Jérôme Chappellaz (Institut des Géosciences de l'Environnement, Grenoble, France) for fruitful discussions of $\mathrm{CO}_{2, \text { atm }}$ variability in MIS 6, and Sophie Hines and Jerry McManus for sharing views on inter-hemispheric climate variability. Allison Jacobel and Babette Hoogakker are thanked for insightful discussions of the $\Delta \delta^{13} \mathrm{C}-\left[\mathrm{O}_{2}\right]$ proxy. We are also grateful to Linda Booth, Adam Scrivner, Tim Setzkorn and Salima Souanef-Ureta for laboratory support, and sincerely thank three anonymous reviewers for their thoughtful and construc- 
tive feedback. Age models for the study cores and data presented in this study are available from the

PANGAEA website (https://doi.pangaea.de/10.1594/PANGAEA.898193).

\section{References}

Abelmann, A., Gersonde, R., Knorr, G., Zhang, X., Chapligin, B., Maier, E., Esper, O., Friedrichsen, H., Lohmann, G., Meyer, H., Tiedemann, R., 2015. The seasonal sea-ice zone in the glacial Southern Ocean as a carbon sink. Nat. Commun. 6, 8136. https://doi.org/10.1038/ncomms9136

Adkins, J.F., 2013. The role of deep ocean circulation in setting glacial climates. Paleoceanography 28, 539-561. https://doi.org/10.1002/palo.20046

Ahn, J., Brook, E.J., 2014. Siple Dome ice reveals two modes of millennial $\mathrm{CO}_{2}$ change during the last ice age. Nat. Commun. 5, 3723. https://doi.org/10.1038/ncomms4723

Anderson, R.F., Ali, S., Bradtmiller, L.I., Nielsen, S.H.H., Fleisher, M.Q., Anderson, B.E., Burckle, L.H., 2009. Wind-driven upwelling in the Southern Ocean and the deglacial rise in atmospheric $\mathrm{CO}_{2}$. Science 323, 1443-1448. https://doi.org/10.1126/science.1167441

Anderson, R.F., Barker, S., Fleisher, M., Gersonde, R., Goldstein S. J. Kuhn, G., Mortyn, P.G., Pahnke, K., Sachs, J.P., 2014a. Biological response to millennial variability of dust supply in the Subantarctic South Atlantic Ocean. Philos. Trans. R. Soc. 372, 20130054. https://doi.org/10.1098/rsta.2013.0054

Anderson, R.F., Barker, S., Fleisher, M., Gersonde, R., Steven, L., Kuhn, G., Mortyn, P.G., Pahnke, K., Julian, P., Goldstein, S.L., Sachs, J.P., 2014b. Biological response to millennial variability of dust and nutrient supply in the Subantarctic South Atlantic Ocean. Philos. Trans. R. Soc. 372, 20130054. https://doi.org/10.1098/rsta.2013.0054

Anderson, R.F., Carr, M.-E., 2010. Uncorking the Southern Ocean's Vintage $\mathrm{CO}_{2}$. Science 328, 1117-1118. https://doi.org/10.1126/science.1190765

Anderson, R.F., Fleisher, M.Q., LeHuray, A.P., 1989. Concentration, oxidation state, and particulate flux of uranium in the Black Sea. Geochim. Cosmochim. Acta 53, 2215-2224. https://doi.org/10.1016/00167037(89)90345-1

Bacastow, B., 1996. The effect of temperature change of the warm surface waters of the oceans on atmospheric $\mathrm{CO}_{2}$. Global Biogeochem. Cycles 10, 319-333. https://doi.org/10.1029/96GB00039

Barker, S., Diz, P., 2014. Timing of the descent into the last ice age determined by the bipolar seesaw. Paleoceanography 29, 489-507. https://doi.org/10.1002/2014PA002623

Barker, S., Elderfield, H., 2002. Foraminiferal calcification response to glacial-interglacial changes in atmospheric $\mathrm{CO}_{2}$. Science 297, 833-836. https://doi.org/10.1126/science.1072815

Barker, S., Greaves, M., Elderfield, H., 2003. A study of cleaning procedures used for foraminiferal $\mathrm{Mg} / \mathrm{Ca}$ paleothermometry. Geochemistry Geophys. Geosystems 4, 8407. https://doi.org/10.1029/2003GC000559

Barker, S., Knorr, G., Edwards, R.L., Parrenin, F., Putnam, A.E., Skinner, L.C., Wolff, E., Ziegler, M., 2011. 800,000 Years of Abrupt Climate Variability. Science 334, 347-351. https://doi.org/10.1126/science. 1203580

Barnes, C.E., Cochran, J.K., 1990. Uranium removal in oceanic sediments and the oceanic U balance. Earth Planet. Sci. Lett. 97, 94-101. https://doi.org/10.1016/0012-821X(90)90101-3

Basak, C., Fröllje, H., Lamy, F., Gersonde, R., Benz, V., Anderson, R.F., Molina-kescher, M., Pahnke, K., 2018. Breakup of last glacial deep stratification in the South Pacific. Science 359, 900-904. https://doi.org/10.1126/science.aao2473

Bazin, L., Landais, A., Lemieux-Dudon, B., Toyé Mahamadou Kele, H., Veres, D., Parrenin, F., Martinerie, P., Ritz, C., Capron, E., Lipenkov, V., M.-F. Loutre, Raynaud, D., Vinther, B., Svensson, A., Rasmussen, S.O., Severi, M., Blunier, T., Leuenberger, M., Fischer, H., Masson-Delmotte, V., Chappellaz, J., Wolff, E., 2013. An optimized multi-proxy, multi-site Antarctic ice and gas orbital chronology (AICC2012): 120800 ka. Clim. Past 9, 1715-1721. https://doi.org/10.5194/cp-9-1715-2013

Benz, V., Esper, O., Gersonde, R., Lamy, F., Tiedemann, R., 2016. Last Glacial Maximum sea surface temperature and sea-ice extent in the Pacific sector of the Southern Ocean. Quat. Sci. Rev. 146, 216-237. https://doi.org/10.1016/j.quascirev.2016.06.006

Bereiter, B., Eggleston, S., Schmitt, J., Nehrbass-Ahles, C., Stocker, T.F., Fischer, H., Kipfstuhl, S., Chappellaz, J., 2015. Revision of the EPICA Dome $\mathrm{C} \mathrm{CO}_{2}$ record from 800 to 600 kyr before present. Geophys. Res. Lett. 42, 542-549. https://doi.org/10.1002/2014GL061957

Bereiter, B., Lüthi, D., Siegrist, M., Schüpbach, S., Stocker, T.F., Fischer, H., 2012. Mode change of millennial $\mathrm{CO}_{2}$ variability during the last glacial cycle associated with a bipolar marine carbon seesaw. Proc. Natl. Acad. Sci. 109, 9755-9760. https://doi.org/110.1073/pnas.1204069109

Bereiter, B., Shackleton, S., Baggenstos, D., Kawamura, K., Severinghaus, J., 2018. Mean global ocean temperatures during the last glacial transition. Nature 553, 39-44. https://doi.org/10.1038/nature25152

Boiteau, R., Greaves, M., Elderfield, H., 2012. Authigenic uranium in foraminiferal coatings: A proxy for ocean 
redox chemistry. Paleoceanography 27, 1-8. https://doi.org/10.1029/2012PA002335

Bouttes, N., Roche, D.M., Paillard, D., 2012. Systematic study of the impact of fresh water fluxes on the glacial carbon cycle. Clim. Past 8, 589-607. https://doi.org/10.5194/cp-8-589-2012

Bozbiyik, A., Steinacher, M., Joos, F., Stocker, T.F., Menviel, L., 2011. Fingerprints of changes in the terrestrial carbon cycle in response to large reorganizations in ocean circulation. Clim. Past 7, 319-338. https://doi.org/10.5194/cp-7-319-2011

Broecker, W.S., Lynch-Stieglitz, J., Archer, D., Hofmann, M., Maier-Reimer, E., Marchal, O., Stocker, T.F., Gruber, N., 1999. How strong is the Harvardton-Bear constraint? Global Biogeochem. Cycles 13, 817820. https://doi.org/10.1029/1999GB900050

Broecker, W.S., Yu, J., Putnam, A.E., 2015. Two contributors to the glacial $\mathrm{CO}_{2}$ decline. Earth Planet. Sci. Lett. 429, 191-196. https://doi.org/10.1016/j.eps1.2015.07.019

Calvert, S.E., Pedersen, T.F., 1996. Sedimentary Geochemistry of Manganese: Implications for the Environment of Formation of Manganiferous Black Shale. Econ. Geol. 91, 36-47. https://doi.org/10.2113/gsecongeo.91.1.36

Cartapanis, O., Galbraith, E.D., Bianchi, D., Jaccard, S.L., 2018. Carbon burial in deep-sea sediment and implications for oceanic inventories of carbon and alkalinity over the last glacial cycle. Clim. Past 14, 1819-1850. https://doi.org/10.5194/cp-2018-49

Carter, L., McCave, I.N., Williams, M.J.M., 2009. Circulation and water masses of the Southern Ocean: A review. Dev. Earth Environ. Sci. 8, 85-114. https://doi.org/10.1016/S1571-9197(08)00004-9

Chalk, T.B., Foster, G.L., Wilson, P.A., 2019. Dynamic storage of glacial $\mathrm{CO}_{2}$ in the Atlantic Ocean revealed by boron $\left[\mathrm{CO}_{3}{ }^{2-}\right]$ and $\mathrm{pH}$ records. Earth Planet. Sci. Lett. 510, 1-11. https://doi.org/10.1016/j.eps1.2018.12.022

Channell, J.E.T., Vázquez Riveiros, N., Gottschalk, J., Waelbroeck, C., Skinner, L.C., 2017. Age and duration of Laschamp and Iceland Basin geomagnetic excursions in the South Atlantic Ocean. Quat. Sci. Rev. 167, 113. https://doi.org/10.1016/j.quascirev.2017.04.020

Charles, C.D., Pahnke, K., Zahn, R., Mortyn, P.G., Ninnemann, U., Hodell, D.A., 2010. Millennial scale evolution of the Southern Ocean chemical divide. Quat. Sci. Rev. 29, 399-409. https://doi.org/10.1016/j.quascirev.2009.09.021

Chase, Z., Kohfeld, K.E., Matsumoto, K., 2015. Controls on biogenic silica burial in the Southern Ocean. Global Biogeochem. Cycles 29, 1-18. https://doi.org/10.1002/2015GB005186

Chen, P., Yu, J., Jin, Z., 2017. An evaluation of benthic foraminiferal U/Ca and U/Mn proxies for deep ocean conditions. Geochemistry Geophys. Geosystems 18, 617-630. https://doi.org/10.1002/2016GC006730

Chiang, J.C.H., Tokos, K.S., Lee, S.Y., Matsumoto, K., 2018. Contrasting Impacts of the South Pacific Split Jet and the Southern Annular Mode Modulation on Southern Ocean Circulation and Biogeochemistry. Paleoceanogr. Paleoclimatology 33, 2-20. https://doi.org/10.1002/2017PA003229

CLIMAP project members, 1984. The Last Interglacial Ocean. Quat. Res. 21, 123-224. https://doi.org/10.1016/0033-5894(84)90098-X

Coplen, B., 1988. Normalization of oxygen and hydrogen isotope data. Chem. Geol. 12, 293-297. https://doi.org/10.1016/0168-9622(88)90042-5

Corliss, B.H., Emerson, S., 1990. Distribution of rose bengal stained deep-sea benthic foraminifera from the Nova Scotian continental margin and Gulf of Maine. Deep Sea Res. Part A. Oceanogr. Res. Pap. 37, 381400. https://doi.org/10.1016/0198-0149(90)90015-N

Dansgaard, W., Johnsen, S.J., Clausen, H.B., Dahl-Jensen, D., Gundestrup, N.S., Hammer, C.U., Hvidberg, C.S., Steffensen, J.P., Sveinbjörnsdottir, A.E., Jouzel, J., Bond, G.C., 1993. Evidence for general instability of past climate from a 250-kyr ice-core record. Nature 364, 218-220. https://doi.org/10.1038/364218a0

de Abreu, L., Shackleton, N.J., Schönfeld, J., Hall, M., Chapman, M., 2003. Millennial-scale oceanic climate variability off the Western Iberian margin during the last two glacial periods. Mar. Geol. 196, 1-20. https://doi.org/10.1016/S0025-3227(03)00046-X

Denton, G.H., Anderson, R.F., Toggweiler, J.R., Edwards, R.L., Schaefer, J.M., Putnam, A.E., 2010. The last glacial termination. Science 328, 1652-1656. https://doi.org/10.1126/science.1184119

Detlef, H., Sosdian, S.M., Kender, S., Lear, C.H., Hall, I.R., 2019. Multi-elemental composition of authigenic carbonates in benthic foraminifera from the eastern Bering Sea continental margin (International Ocean Discovery Program Site U1343). Geochim. Cosmochim. Acta. https://doi.org/10.1016/j.gca.2019.09.025

EPICA Community Members, 2006. One-to-one coupling of glacial climate variability in Greenland and Antarctica. Nature 444, 195-198. https://doi.org/10.1038/nature05301

Eppley, R.W., 1972. Temperature and phytoplankton growth in the sea. Fish. Bull. 70, 1063-1085.

Ferrari, R., Jansen, M.F., Adkins, J.F., Burke, A., Stewart, A.L., Thompson, A.F., 2014. Antarctic sea ice control on ocean circulation in present and glacial climates. Proc. Natl. Acad. Sci. 111, 8753-8758. https://doi.org/10.1073/pnas.1323922111

Fischer, H., Schmitt, J., Lüthi, D., Stocker, T.F., Tschumi, T., Parekh, P., Joos, F., Köhler, P., Barbante, C., Le Floch, M., Raynaud, D., Wolff, E., 2010. The role of Southern Ocean processes in orbital and millennial 
$\mathrm{CO}_{2}$ variations - A synthesis. Quat. Sci. Rev. 29, 193-205. https://doi.org/10.1016/j.quascirev.2009.06.007 François, R., Altabet, M.A., Yu, E.F., Sigman, D.M., Bacon, M.P., Frank, M., Bohrmann, G., Bareille, G., Labeyrie, L.D., 1997. Contribution of Southern Ocean surface-water stratification to low atmospheric $\mathrm{CO}_{2}$ concentrations during the last glacial period. Nature 389, 929-936. https://doi.org/10.1038/40073

Froelich, P.N., Klinkhammer, G.P., Bender, M.L., Luedtke, N.A., Heath, G.R., Cullen, D., Dauphin, P., Hammond, D., Hartman, B., 1979. Early oxidation of organic matter in pelagic sediments of the eastern equatorial Atlantic: suboxic diagenesis. Geochim. Cosmochim. Acta 43, 1075-1090.

Galbraith, E.D., Jaccard, S.L., 2015. Deglacial weakening of the oceanic soft tissue pump: global constraints from sedimentary nitrogen isotopes and oxygenation proxies. Quat. Sci. Rev. 109, 38-48. https://doi.org/10.1016/j.quascirev.2014.11.012

Garcia, H.E., Locarnini, R.A., Boyer, T.P., Antonov, J.I., Baranova, O.K., Zweng, M.M., Johnson, D.R., 2010. World Ocean Atlas 2009, Volume 3: Dissolved Oxygen, Apparent Oxygen Utilization, and Oxygen Saturation, NOAA Atlas NESDIS 70. National Oceanic and Atmospheric Administration, U.S. Government Printing Office, Washington, D.C.

Garcia, H.E., Locarnini, R.A., Boyer, T.P., Antonov, J.I., Baranova, O.K., Zweng, M.M., Reagan, J.R., Johnson, D.R., 2014. World Ocean Atlas 2013, Volume 3: Dissolved Oxygen, Apparent Oxygen Utilization, and Oxygen Saturation., in: Levitus, S., Mishonov, A. V (Eds.), NOAA Atlas NESDIS 75. p. 27.

Gebbie, G., Huybers, P., 2011. How is the ocean filled? Geophys. Res. Lett. 38, L6604-L6604. https://doi.org/10.1029/2011GL046769

Gersonde, R., Abelmann, A., Brathauer, U., Becquey, S., Bianchi, C., Cortese, G., Grobe, H., Kuhn, G., Niebler, H.-S., Segl, M., Sieger, M., Zielinski, U., Fütterer, D.K., 2003. Last glacial sea surface temperatures and sea-ice extent in the Southern Ocean (Atlantic-Indian sector): A multiproxy approach. Paleoceanography 18, 1-6. https://doi.org/10.1029/2002PA000809

Geslin, E., Heinz, P., Jorissen, F., Hemleben, C., 2004. Migratory responses of deep-sea benthic foraminifera to variable oxygen conditions: laboratory investigations. Mar. Micropaleontol. 53, 227-243. https://doi.org/10.1016/j.marmicro.2004.05.010

Glock, N., Roy, A.S., Romero, D., Wein, T., Weissenbach, J., Revsbech, N.P., Høgslund, S., Clemens, D., Sommer, S., Dagan, T., 2019. Metabolic preference of nitrate over oxygen as an electron acceptor in foraminifera from the Peruvian oxygen minimum zone. Proc. Natl. Acad. Sci. 116, 2860-2865. https://doi.org/10.1073/pnas.1813887116

Gottschalk, J., Battaglia, G., Fischer, H., Frölicher, T., Jaccard, S.L., Jeltsch-Thömmes, A., Joos, F., Köhler, P., Meissner, K.J., Menviel, L., Nehrbass-Ahles, C., Schmitt, J., Schmittner, A., Skinner, L.C., Stocker, T.F., 2019. Mechanisms of millennial-scale atmospheric $\mathrm{CO}_{2}$ change in numerical model simulations. Quat. Sci. Rev. 220, 30-74. https://doi.org/10.1016/j.quascirev.2019.05.013

Gottschalk, J., Hodell, D.A., Skinner, L.C., Crowhurst, S.J., Jaccard, S.L., Charles, C.D., 2018. Implications of past carbonate preservation events in the deep Southeast Atlantic (Cape Basin) for Atlantic overturning dynamics and the global carbon cycle. Paleoceanogr. Paleoclimatology 33, 1-21. https://doi.org/10.1029/2018PA003353

Gottschalk, J., Riveiros, N.V., Waelbroeck, C., Skinner, L.C., Michel, E., Duplessy, J.-C., Hodell, D., Mackensen, A., 2016a. Carbon isotope offsets between species of the genus Cibicides (Cibicidoides) in the glacial sub-Antarctic Atlantic Ocean. Paleoceanography 31, 1583-1602. https://doi.org/10.1002/2016PA003029

Gottschalk, J., Skinner, L.C., Lippold, J., Vogel, H., Frank, N., Jaccard, S.L., Waelbroeck, C., 2016b. Biological and physical controls in the Southern Ocean on past millennial-scale atmospheric $\mathrm{CO}_{2}$ changes. Nat. Commun. 7, 1-11. https://doi.org/10.1038/ncomms11539

Gottschalk, J., Skinner, L.C., Misra, S., Waelbroeck, C., Menviel, L., Timmermann, A., 2015a. Abrupt changes in the southern extent of North Atlantic Deep Water during Dansgaard-Oeschger events. Nat. Geosci. 8, 950-955. https://doi.org/10.1038/ngeo2558

Gottschalk, J., Skinner, L.C., Waelbroeck, C., 2015b. Contribution of seasonal sub-Antarctic surface water variability to millennial-scale changes in atmospheric $\mathrm{CO}_{2}$ over the last deglaciation and Marine Isotope Stage 3. Earth Planet. Sci. Lett. 411, 87-99. https://doi.org/10.1016/j.eps1.2014.11.051

Haddam, N.A., Michel, E., Siani, G., Cortese, G., Bostock, H.C., Duprat, J.M., Isguder, G., 2016. Improving past sea surface temperature reconstructions from the Southern Hemisphere oceans using planktonic foraminiferal census data. Paleoceanography 31, 822-837. https://doi.org/10.1002/2016PA002946

Hain, M.P., Sigman, D.M., Haug, G.H., 2010. Carbon dioxide effects of Antarctic stratification, North Atlantic Intermediate Water formation, and subantarctic nutrient drawdown during the last ice age: Diagnosis and synthesis in a geochemical box model. Global Biogeochem. Cycles 24, GB4023-GB4023. https://doi.org/10.1029/2010GB003790

Hasenfratz, A.P., Martínez-García, A., Jaccard, S.L., Vance, D., Wälle, M., Greaves, M., Haug, G.H., 2016. Determination of the $\mathrm{Mg} / \mathrm{Mn}$ ratio in foraminiferal coatings: An approach to correct $\mathrm{Mg} / \mathrm{Ca}$ temperatures for Mn-rich contaminant phases. Earth Planet. Sci. Lett. 457, 335-347. 
https://doi.org/10.1016/j.eps1.2016.10.004

Haslett, J., Parnell, A., 2008. A simple monotone process with application to radiocarbon-dated depth chronologies. J. R. Stat. Soc. 57, 399-418. https://doi.org/10.1111/j.1467-9876.2008.00623.x

Hemming, S.R., 2004. Heinrich events: Massive late Pleistocene detritus layers of the North Atlantic and their global climate imprint. Rev. Geophys. 42, RG1005. https://doi.org/10.1029/2003RG000128

Henry, L.G., McManus, J.F., Curry, W.B., Roberts, N.L., Piotrowski, A.M., Keigwin, L.D., 2016. North Atlantic ocean circulation and abrupt climate change during the last glaciation. Science 353, 470-474. https://doi.org/10.1126/science.aaf5529

Hoogakker, B.A.A., Elderfield, H., Schmiedl, G., McCave, I.N., Rickaby, R.E.M., 2015. Glacial-interglacial changes in bottom-water oxygen content on the Portuguese margin. Nat. Geosci. 8, 40-43. https://doi.org/10.1038/ngeo2317

Huybers, P., Langmuir, C., 2009. Feedback between deglaciation, volcanism, and atmospheric $\mathrm{CO}_{2}$. Earth Planet. Sci. Lett. 286, 479-491. https://doi.org/10.1016/j.eps1.2009.07.014

Ito, T., Follows, M.J., 2005. Preformed phosphate, soft tissue pump and atmospheric $\mathrm{CO}_{2}$. J. Mar. Res. 63, 813839. https://doi.org/10.1357/0022240054663231

Jaccard, S.L., Galbraith, E.D., 2012. Large climate-driven changes of oceanic oxygen concentrations during the last deglaciation. Nat. Geosci. 5, 151-156. https://doi.org/10.1038/ngeo1352

Jaccard, S.L., Galbraith, E.D., Frölicher, T.L., Gruber, N., 2014. Ocean (de)oxygenation across the last deglaciation: Insights for the future. Oceanography 27, 26-35. https://doi.org/10.5670/oceanog.2014.05.

Jaccard, S.L., Galbraith, E.D., Martínez-Garcia, A., Anderson, R.F., 2016. Covariation of abyssal Southern Ocean oxygenation and $\mathrm{pCO}_{2}$ throughout the last ice age. Nature 530, 207-210. https://doi.org/10.1038/nature16514

Jaccard, S.L., Hayes, C.T., Martínez-García, A., Hodell, D.A., Anderson, R.F., Sigman, D.M., Haug, G.H., 2013. Two Modes of Change in Southern Ocean Productivity Over the Past Million Years. Science 339, 14191423. https://doi.org/10.1126/science. 1227545

Jouzel, J., Masson-Delmotte, V., Cattani, O., Dreyfus, G., Falourd, S., Hoffmann, G., Minster, B., Nouet, J., Barnola, J.M., Chappellaz, J., Fischer, H., Gallet, J.C., Johnsen, S., Leuenberger, M., Loulergue, L., Luethi, D., Oerter, H., Parrenin, F., Raisbeck, G., Raynaud, D., Schilt, A., Schwander, J., Selmo, E., Souchez, R., Spahni, R., Stauffer, B., Steffensen, J.P., Stenni, B., Stocker, T.F., Tison, J.L., Werner, M., Wolff, E.W., 2007. Orbital and millennial Antarctic climate variability over the past 800,000 years. Science 317, 793-796. https://doi.org/10.1126/science.1141038

Kanfoush, S.L., Hodell, D.A., Charles, C.D., Guilderson, T.P., Mortyn, P.G., Ninnemann, U.S., 2000. Millennial-scale instability of the Antarctic ice sheet during the last glaciation. Science 288, 1815-1818. https://doi.org/10.1126/science.288.5472.1815

Kasten, S., Zabel, M., Heuer, V., Hensen, C., 2003. Processes and signals of non-steady state diagenesis in deepsea sediments and their pore waters, in: Wefer, G., Mulitza, S., Ratmeyer, V. (Eds.), The South Atlantic in the Late Quaternary: Reconstruction of Material Budgets and Current Systems. Springer-Verlag Berlin Heidelberg New York Tokyo, pp. 431-459.

Key, R.M., Kozyr, A., Sabine, C.L., Lee, K., Wanninkhof, R., Bullister, J.L., Feely, R.A., Millero, F.J., Mordy, C., Peng, T.-H., 2004. A global ocean carbon climatology: Results from Global Data Analysis Project (GLODAP). Global Biogeochem. Cycles 18, GB4031-GB4031. https://doi.org/10.1029/2004GB002247

Klinkhammer, G.P., Palmer, M.R., 1991. Uranium in the oceans: where it goes and why. Geochim. Cosmochim. Acta 55, 1799-1806. https://doi.org/10.1016/0016-7037(91)90024-Y

Köhler, P., Joos, F., Gerber, S., Knutti, R., 2005. Simulated changes in vegetation distribution, land carbon storage, and atmospheric $\mathrm{CO}_{2}$ in response to a collapse of the North Atlantic thermohaline circulation. Clim. Dyn. 25, 689-708. https://doi.org/10.1007/s00382-005-0058-8

Köhler, P., Knorr, G., Bard, E., 2014. Permafrost thawing as a possible source of abrupt carbon release at the onset of the Bølling/Allerød. Nat. Commun. 5. https://doi.org/10.1038/ncomms6520

Köhler, P., Nehrbass-Ahles, C., Schmitt, J., Stocker, T.F., Fischer, H., 2017. A 156 kyr smoothed history of the atmospheric greenhouse gases $\mathrm{CO}_{2}, \mathrm{CH}_{4}$, and $\mathrm{N}_{2} \mathrm{O}$ and their radiative forcing. Earth Syst. Sci. Data 9 , 363-387. https://doi.org/10.5194/essd-9-363-2017

Kroopnick, P.M., 1985. The distribution of ${ }^{13} \mathrm{C}$ of Sigma $\mathrm{CO}_{2}$ in the world oceans. Deep Sea Res. 32, 57-84. https://doi.org/10.1016/0198-0149(85)90017-2

Kumar, N., Anderson, R.F., Mortlock, R.A., Froelich, P.N., Kubik, P., Dittrich-Hannen, B., Suter, M., 1995. Increased biological productivity and export production in the glacial Southern Ocean. Nature 378, 675680. https://doi.org/10.1038/378675a0

Kurahashi-Nakamura, T., Abe-Ouchi, A., Yamanaka, Y., Misumi, K., 2007. Compound effects of Antarctic sea ice on atmospheric $\mathrm{pCO}_{2}$ change during glacial-interglacial cycle. Geophys. Res. Lett. 34, 1-5. https://doi.org/10.1029/2007GL030898

Kwon, E.Y., Primeau, F., Sarmiento, J.L., 2009. The impact of remineralization depth on the air--sea carbon balance. Nat. Geosci. 2, 630-635. https://doi.org/10.1038/ngeo612 
Lambert, F., Bigler, M., Steffensen, J.P., Hutterli, M., Fischer, H., 2012. Centennial mineral dust variability in high-resolution ice core data from Dome C, Antarctica. Clim. Past 8, 609-623. https://doi.org/10.5194/cp8-609-2012

Lamy, F., Gersonde, R., Winckler, G., Esper, O., Jaeschke, A., Kuhn, G., Ullermann, J., Martinez-Garcia, A., Lambert, F., Kilian, R., 2014. Increased Dust Deposition in the Pacific Southern Ocean During Glacial Periods. Science 343, 403-407. https://doi.org/10.1126/science.1245424

Lear, C.H., Billups, K., Rickaby, R.E.M., Diester-Haass, L., Mawbey, E.M., Sosdian, S.M., 2016. Breathing more deeply: Deep ocean carbon storage during the mid-Pleistocene climate transition. Geology G38636.1-G38636.1. https://doi.org/10.1130/G38636.1

Lee, S.Y., Chiang, J.C.H., Matsumoto, K., Tokos, K.S., 2011. Southern Ocean wind response to North Atlantic cooling and the rise in atmospheric $\mathrm{CO}_{2}$ : Modeling perspective and paleoceanographic implications. Paleoceanography 26, 1214. https://doi.org/10.1029/2010PA002004

Lund, D.C., Asimow, P.D., Farley, K.A., Rooney, T.O., Seeley, E., Jackson, E.W., Durham, Z.M., 2016. Enhanced East Pacific Rise hydrothermal activity during the last two glacial terminations. Science 351, 478-482. https://doi.org/10.1126/science.aad4296

Marchal, O., Stocker, T.F., Joos, F., 1998. Impact of oceanic reorganizations on the ocean carbon cycle and atmospheric carbon dioxide content. Paleoceanography 13, 225-244. https://doi.org/10.1029/98PA00726

Margari, V., Skinner, L.C., Tzedakis, P.C., Ganopolski, A., Vautravers, M., Shackleton, N.J., 2010. The nature of millennial-scale climate variability during the past two glacial periods. Nat. Geosci. 3, 127-131. https://doi.org/10.1038/ngeo740

Marinov, I., Gnanadesikan, A., Toggweiler, J.R., Sarmiento, J.L., 2006. The Southern Ocean biogeochemical divide. Nature 441, 964-967. https://doi.org/10.1038/nature04883

Martin, J.H., 1990. Glacial-interglacial $\mathrm{CO}_{2}$ change: The iron hypothesis. Paleoceanography 5, 1-13. https://doi.org/10.1029/PA005i001p00001

Martínez-García, A., Sigman, D.M., Ren, H., Anderson, R.F., Straub, M., Hodell, D.A., Jaccard, S.L., Eglinton, T.I., Haug, G.H., 2014. Iron Fertilization of the Subantarctic Ocean During the Last Ice Age. Science 343, 1347-1350. https://doi.org/10.1126/science.1246848

Martrat, B., Grimalt, J.O., Shackleton, N.J., de Abreu, L., Hutterli, M.A., Stocker, T.F., 2007. Four climate cycles of recurring deep and surface water destabilizations on the Iberian margin. Science 317, 502-507. https://doi.org/10.1126/science.1139994

Matsumoto, K., 2007. Biology-mediated temperature control on atmospheric $\mathrm{pCO}_{2}$ and ocean biogeochemistry. Geophys. Res. Lett. 34, L20605-L20605. https://doi.org/10.1029/2007GL031301

Matsumoto, K., Hashioka, T., Yamanaka, Y., 2007. Effect of temperature-dependent organic carbon decay on atmospheric $\mathrm{pCO}_{2}$. J. Geophys. Res. 112, 1-9. https://doi.org/10.1029/2006JG000187

McCorkle, D.C., Emerson, S.R., 1988. The relationship between pore water carbon isotopic composition and bottom water oxygen concentration. Geochim. Cosmochim. Acta 52, 1169-1178. https://doi.org/10.1016/0016-7037(88)90270-0

McCorkle, D.C., Keigwin, L.D., Corliss, B.H., Emerson, S.R., 1990. The influence of microhabitats on the carbon isotopic composition of deep-sea benthic foraminifera. Paleoceanography 5, 161-185. https://doi.org/10.1029/PA005i002p00161

McManus, J., Berelson, W.M., Klinkhammer, G.P., Hammond, D.E., Holm, C., 2005. Authigenic uranium: relationship to oxygen penetration depth and organic carbon rain. Geochim. Cosmochim. Acta 69, 95-108. https://doi.org/10.1016/j.gca.2004.06.023

McManus, J., Berelson, W.M., Severmann, S., Poulson, R.L., Hammond, D.E., Klinkhammer, G.P., Holm, C., 2006. Molybdenum and uranium geochemistry in continental margin sediments: Paleoproxy potential. Geochim. Cosmochim. Acta 70, 4643-4662. https://doi.org/10.1016/j.gca.2006.06.1564

Menviel, L., England, M.H., Meissner, K.J., Mouchet, A., Yu, J., 2014. Atlantic-Pacific seesaw and its role in outgassing $\mathrm{CO}_{2}$ during Heinrich events. Paleoceanography 29, 58-70. https://doi.org/10.1002/2013PA002542

Menviel, L., Mouchet, A., Meissner, K.J., Joos, F., England, M.H., 2015a. Impact of oceanic circulation changes on atmospheric $\delta^{13} \mathrm{CO}_{2}$. Global Biogeochem. Cycles 29, 1944-1961. https://doi.org/10.1002/2015GB005207

Menviel, L., Spence, P., England, M.H., 2015b. Contribution of enhanced Antarctic Bottom Water formation to Antarctic warm events and millennial-scale atmospheric $\mathrm{CO}_{2}$ increase. Earth Planet. Sci. Lett. 413, 37-50. https://doi.org/10.1016/j.eps1.2014.12.050

Menviel, L., Spence, P., Yu, J., Chamberlain, M.A., Matear, R.J., Meissner, K.J., England, M.H., 2018. Southern Hemisphere westerlies as a driver of the early deglacial atmospheric $\mathrm{CO}_{2}$ rise. Nat. Commun. 9, 2503. https://doi.org/10.1038/s41467-018-04876-4

Menviel, L., Timmermann, A., Mouchet, A., Timm, O., 2008. Meridional reorganizations of marine and terrestrial productivity during Heinrich events. Paleoceanography 23, PA1203. https://doi.org/10.1029/2007PA001445 
Menviel, L., Yu, J., Joos, F., Mouchet, A., Meissner, K.J., England, M.H., 2017. Poorly ventilated deep ocean at the Last Glacial Maximum inferred from carbon isotopes: A data-model comparison study. Paleoceanography 32, 2-17. https://doi.org/10.1002/2016PA003024

Morford, J.L., Emerson, S., 1999. The geochemistry of redox sensitive trace metals in sediments. Geochim. Cosmochim. Acta 63, 1735-1750. https://doi.org/10.1016/S0016-7037(99)00126-X

NGRIP members, 2004. High-resolution record of Northern Hemisphere climate extending into the last interglacial period. Nature 431, 147-151. https://doi.org/10.1038/nature02805

Nielsen, S.H.H., Hodell, D.A., Kamenov, G., Guilderson, T., Perfit, M.R., 2007. Origin and significance of icerafted detritus in the Atlantic sector of the Southern Ocean. Geochemistry Geophys. Geosystems 8, Q12005-Q12005. https://doi.org/10.1029/2007GC001618

Ödalen, M., Nycander, J., Oliver, K.I.C., Brodeau, L., Ridgwell, A., 2018. The influence of the ocean circulation state on ocean carbon storage and $\mathrm{CO}_{2}$ drawdown potential in an Earth system model. Biogeosciences 15, 1367-1393. https://doi.org/10.5194/bg-15-1367-2018

Orsi, A.H., Whitworth, T., Nowlin, W.D., 1995. On the meridional extent and fronts of the Antarctic Circumpolar Current. Deep Sea Res. 42, 641-673. https://doi.org/10.1016/0967-0637(95)00021-W

Pedro, J.B., Jochum, M., Buizert, C., He, F., Barker, S., Rasmussen, S.O., 2018. Beyond the bipolar seesaw: Toward a process understanding of interhemispheric coupling. Quat. Sci. Rev. 192, 27-46. https://doi.org/10.1016/j.quascirev.2018.05.005

Pena, L.D., Cacho, I., Calvo, E., Pelejero, C., Eggins, S., Sadekov, A., 2008. Characterization of contaminant phases in foraminifera carbonates by electron microprobe mapping. Geochemistry Geophys. Geosystems 1-12. https://doi.org/10.1029/2008GC002018

Pena, L.D., Calvo, E., Cacho, I., Eggins, S., Pelejero, C., 2005. Identification and removal of Mn-Mg-rich contaminant phases on foraminiferal tests: Implications for $\mathrm{Mg} / \mathrm{Ca}$ past temperature reconstructions. Geochemistry Geophys. Geosystems 6, Q09P02-Q09P02. https://doi.org/10.1029/2005GC000930

Petit, J.-R., Jouzel, J., Raynaud, D., Barkov, N.I., Barnola, J.-M., Basile, I., Bender, M., Chappellaz, J., Davis, M., Delaygue, G., Delmotte, M., Kotlyakov, V.M., Legrand, M., Lipenkov, V.Y., Lorius, C., L. Pepin, L., Ritz, C., Saltzman, E., Stievenard, M., 1999. Climate and atmospheric history of the past 420,000 years from the Vostok ice core, Antarctica. Nature 399, 429-436. https://doi.org/10.1038/20859

Piña-Ochoa, E., Koho, K.A., Geslin, E., Risgaard-Petersen, N., 2010. Survival and life strategy of the foraminiferan Globobulimina turgida through nitrate storage and denitrification. Mar. Ecol. Prog. Ser. 417, 39-49. https://doi.org/10.3354/meps08805

Policy, H.W., Johnson, H.B., Marinot, B.D., Mayeux, H.S., 1993. Increase in C3 plant water-use efficiency and biomass over glacial to present $\mathrm{CO}_{2}$ concentrations. Nature 361, 61. https://doi.org/10.1038/361061a0

Primeau, F., 2005. Characterizing transport between the surface mixed layer and the ocean interior with a forward and adjoint global ocean transport model. J. Phys. Oceanogr. 35, 545-564. https://doi.org/10.1175/JPO2699.1

Rae, J.W.B., Burke, A., Robinson, L.F., Adkins, J.F., Chen, T., Cole, C., Greenop, R., Li, T., Littley, E.F.M., Nita, D.C., Stewart, J.A., Taylor, B.J., 2018. $\mathrm{CO}_{2}$ storage and release in the deep Southern Ocean on millennial to centennial timescales. Nature 562, 569-573. https://doi.org/10.1038/s41586-018-0614-0

Raitzsch, M., Kuhnert, H., Hathorne, C., Groeneveld, J., Bickert, T., 2011. U/Ca in benthic foraminifers: A proxy for the deep-sea carbonate saturation. Geochemistry Geophys. Geosystems 12, Q06019-Q06019. https://doi.org/10.1029/2010GC003344

Risgaard-Petersen, N., Langezaal, A.M., Ingvardsen, S., Schmid, M.C., Jetten, M.S.M., Op Den Camp, H.J.M., Derksen, J.W.M., Piña-Ochoa, E., Eriksson, S.P., Nielsen, L.P., Revsbech, N.P., Cedhagen, T., Van Der Zwaan, G.J., 2006. Evidence for complete denitrification in a benthic foraminifer. Nature 443, 93-96. https://doi.org/10.1038/nature05070

Roberts, J., Gottschalk, J., Skinner, L.C., Peck, V.L., Kender, S., Elderfield, H., Waelbroeck, C., Vázquez Riveiros, N., Hodell, D.A., 2015. Evolution of South Atlantic density and chemical stratification across the last deglaciation. Proc. Natl. Acad. Sci. 113, 514-519. https://doi.org/10.1073/pnas.1511252113

Ronge, T.A., Tiedemann, R., Lamy, F., Köhler, P., Alloway, B. V, De Pol-Holz, R., Pahnke, K., Southon, J., Wacker, L., 2016. Radiocarbon constraints on the extent and evolution of the South Pacific glacial carbon pool. Nat. Commun. 7, 11487. https://doi.org/10.1038/ncomms11487

Russell, A.D., Hönisch, B., Spero, H.J., Lea, D.W., 2004. Effects of seawater carbonate ion concentration and temperature on shell $\mathrm{U}, \mathrm{Mg}$, and $\mathrm{Sr}$ in cultured planktonic foraminifera. Geochim. Cosmochim. Acta 68, 4347-4361. https://doi.org/10.1016/j.gca.2004.03.013

Sarmiento, J.L., Toggweiler, J.R., 1984. A new model for the role of the oceans in determining atmospheric $\mathrm{pCO}_{2}$. Nature 308, 621-624. https://doi.org/10.1038/308621a0

Schmittner, A., Brook, E.J., Ahn, J., 2007. Impact of the Ocean's Overturning Circulation on Atmospheric $\mathrm{CO}_{2}$, in: Schmittner, A., Chiang, J.C.H., Hemming, S.R. (Eds.), Geophysical Monograph Series 173: Ocean Circulation: Mechanisms and Impacts. American Geophysical Union, Washington, DC, USA, pp. 209246. https://doi.org/10.1029/173GM20 
Schmittner, A., Galbraith, E.D., 2008. Glacial greenhouse-gas fluctuations controlled by ocean circulation changes. Nature 456, 373-376. https://doi.org/10.1038/nature07531

Schmittner, A., Lund, D.C., 2015. Early deglacial Atlantic overturning decline and its role in atmospheric $\mathrm{CO}_{2}$ rise inferred from carbon isotopes $\left(\delta^{13} \mathrm{C}\right)$. Clim. Past 11, 135-152. https://doi.org/10.5194/cp-11-135-2015

Schneider, R., Schmitt, J., Köhler, P., Joos, F., Fischer, H., 2013. A reconstruction of atmospheric carbon dioxide and its stable carbon isotopic composition from the penultimate glacial maximum to the last glacial inception. Clim. Past 9, 2507-2523. https://doi.org/10.5194/cp-9-2507-2013

Shoenfelt, E.M., Winckler, G., Lamy, F., Anderson, R.F., Bostick, B.C., 2018. Highly bioavailable dust-borne iron delivered to the Southern Ocean during glacial periods. Proc. Natl. Acad. Sci. 115, 11180-11185. https://doi.org/10.1073/pnas.1809755115

Sigman, D.M., Boyle, E.A., 2000. Glacial/interglacial variations in atmospheric carbon dioxide. Nature 407, 859-869. https://doi.org/10.1038/35038000

Sigman, D.M., De Boer, A.M., Haug, G.H., 2007. Antarctic stratification, atmospheric water vapor, and Heinrich events: A hypothesis for late Pleistocene deglaciations. Ocean Circ. Mech. Impacts-Past Futur. Chang. Merid. Overturning 335-349.

Sigman, D.M., Hain, M.P., Haug, G.H., 2010. The polar ocean and glacial cycles in atmospheric $\mathrm{CO}_{2}$ concentration. Nature 466, 47-55. https://doi.org/10.1038/nature09149

Sikes, E.L., Cook, M.S., Guilderson, T.P., 2016. Reduced deep ocean ventilation in the Southern Pacific Ocean during the last glaciation persisted into the deglaciation. Earth Planet. Sci. Lett. 438, 130-138. https://doi.org/10.1016/j.epsl.2015.12.039

Skinner, L.C., Elderfield, H., Hall, M., 2007. Phasing of Millennial Climate Events and Northeast Atlantic DeepWater Temperature Change Since 50 Ka BP, in: Schmittner, A., Chiang, J.C.H., Hemming, S.R. (Eds.), Ocean Circulation: Mechanisms and Impacts. American Geophysical Union, Geophysical Monograph Series, pp. 197-208. https://doi.org/10.1029/173GM14

Skinner, L.C., Fallon, S., Waelbroeck, C., Michel, E., Barker, S., 2010. Ventilation of the deep Southern Ocean and deglacial $\mathrm{CO}_{2}$ rise. Science 328, 1147-1151. https://doi.org/10.1126/science.1183627

Skinner, L.C., Sadekov, A., Brandon, M., Greaves, M., Plancherel, Y., de la Fuente, M., Gottschalk, J., SouanefUreta, S., Sevilgen, D.S., Scrivner, A.E., 2019. Rare Earth Elements in early-diagenetic foraminifer 'coatings': pore-water controls and potential palaeoceanographic applications. Geochim. Cosmochim. Acta 245, 118-132. https://doi.org/10.1016/j.gca.2018.10.027

Skinner, L.C., Shackleton, N.J., 2005. An Atlantic lead over Pacific deep-water change across Termination I: implications for the application of the marine isotope stage stratigraphy. Quat. Sci. Rev. 24, 571-580. https://doi.org/10.1016/j.quascirev.2004.11.008

Skinner, L.C., Waelbroeck, C., Scrivner, A.E., Fallon, S.J., 2014. Radiocarbon evidence for alternating northern and southern sources of ventilation of the deep Atlantic carbon pool during the last deglaciation. Proc. Natl. Acad. Sci. 111, 5480-5484. https://doi.org/10.1073/pnas.1400668111

Sokolov, S., Rintoul, S.R., 2009. Circumpolar structure and distribution of the Antarctic Circumpolar Current fronts: 2. Variability and relationship to sea surface height. J. Geophys. Res. Ocean. 114. https://doi.org/10.1029/2008JC005108

Stephens, B.B., Keeling, R.F., 2000. The influence of Antarctic sea ice on glacial-interglacial $\mathrm{CO}_{2}$ variations. Nature 404, 171-174. https://doi.org/10.1038/35004556

Studer, A.S., Sigman, D.M., Martínez-García, A., Benz, V., Winckler, G., Kuhn, G., Esper, O., Lamy, F., Jaccard, S.L., Wacker, L., Oleynik, S., Gersonde, R., Haug, G.H., 2015. Antarctic Zone nutrient conditions during the last two glacial cycles. Paleoceanography 30, 845-862. https://doi.org/10.1002/2014PA002745

Sun, X., Matsumoto, K., 2010. Effects of sea ice on atmospheric $\mathrm{pCO}_{2}$ : A revised view and implications for glacial and future climates. J. Geophys. Res. 115, 1-8. https://doi.org/10.1029/2009JG001023

Svendsen, J.I., Alexanderson, H., Astakhov, V.I., Demidov, I., Dowdeswell, J.A., Funder, S., Gataullin, V., Henriksen, M., Hjort, C., Houmark-Nielsen, M., Hubberten, H.W., Ingólfsson, Ó., Jakobsson, M., Kjær, K.H., Larsen, E., Lokrantz, H., Lunkka, J.P., Lyså, A., Mangerud, J., Matiouchkov, A., Murray, A., Möller, P., Niessen, F., Nikolskaya, O., Polyak, L., Saarnisto, M., Siegert, C., Siegert, M.J., Spielhagen, R.F., Stein, R., 2004. Late Quaternary ice sheet history of northern Eurasia. Quat. Sci. Rev. 23, 12291271. https://doi.org/10.1016/j.quascirev.2003.12.008

Takahashi, T., Sutherland, S.C., Sweeney, C., Poisson, A., Metzl, N., Tilbrook, B., Bates, N., Wanninkhof, R., Feely, R.A., Sabine, C., Olafssong, J., Nojirih, Y., 2002. Global sea-air $\mathrm{CO}_{2}$ flux based on climatological surface ocean $\mathrm{pCO}_{2}$, and seasonal biological and temperature effects. Deep Sea Res. 49, 1601-1622. https://doi.org/10.1016/S0967-0645(02)00003-6

Talley, L.D., 2013. Closure of the global overturning circulation through the Indian, Pacific, and Southern Oceans: Schematics and transports. Oceanography 26, 80-97. https://doi.org/10.5670/oceanog.2013.07

Tesi, T., Muschitiello, F., Smittenberg, R.H., Jakobsson, M., Vonk, J.E., Hill, P., Andersson, A., Kirchner, N., Noormets, R., Dudarev, O., Semiletov, I., Gustafsson, Ö., 2016. Massive remobilization of permafrost carbon during post-glacial warming. Nat. Commun. 7, 13653. https://doi.org/10.1038/ncomms13653 
Toggweiler, J.R., Russell, J.L., Carson, S.R., 2006. Midlatitude westerlies, atmospheric $\mathrm{CO}_{2}$, and climate change during the ice ages. Paleoceanography 21, 2005. https://doi.org/10.1029/2005PA001154

Tribovillard, N., Algeo, T.J., Lyons, T., Riboulleau, A., 2006. Trace metals as paleoredox and paleoproductivity proxies: An update. Chem. Geol. 232, 12-32. https://doi.org/j.chemgeo.2006.02.012

Umling, N.E., Thunell, R.C., 2017. Synchronous deglacial thermocline and deep-water ventilation in the eastern equatorial Pacific. Nat. Commun. 8, 1-10. https://doi.org/10.1038/ncomms14203

Vázquez Riveiros, N., Waelbroeck, C., Skinner, L.C., Roche, D.M., Duplessy, J.C., Michel, E., 2010. Response of South Atlantic deep waters to deglacial warming during Terminations V and I. Earth Planet. Sci. Lett. 298, 323-333. https://doi.org/10.1016/j.epsl.2010.08.003

Veres, D., Bazin, L., Landais, A., Kele, H.T.M., Lemieux-Dudon, B., Parrenin, F., Martinerie, P., Blayo, E., Blunier, T., Capron, E., Chappellaz, J., Rasmussen, S.O., Severi, M., Svensson, A., Vinther, B.M., Wolff, E., 2013. The Antarctic ice core chronology (AICC2012): an optimized multi-parameter and multi-site dating approach for the last 120 thousand years. Clim. Past 9, 1733-1748. https://doi.org/10.5194/cpd-86011-2012

Vogel, H., Meyer-Jacob, C., Thöle, L., Lippold, J., Jaccard, S.L., 2016. Quantification of biogenic silica by means of Fourier transform infrared spectroscopy (FTIRS) in marine sediments. Limnol. Oceanogr. Methods 14, 828-838. https://doi.org/10.1002/lom3.10129

Volk, T., Hoffert, M.I., 1985. Ocean Carbon Pumps: Analysis of Relative Strengths and Efficiencies in OceanDriven Atmospheric $\mathrm{CO}_{2}$ Changes, in: Sundquist, E.T., Broecker, W.S. (Eds.), The Carbon Cycle and Atmospheric CO2: Natural Variations Archean to Present, Geophysical Monograph Series. pp. 99-110. https://doi.org/10.1029/GM032p0099

Völker, C., Köhler, P., 2013. Responses of ocean circulation and carbon cycle to changes in the position of the Southern Hemisphere westerlies at Last Glacial Maximum. Paleoceanography 28, 726-739. https://doi.org/10.1002/2013PA002556

Watson, A.J., Naveira Garabato, A.C., 2006. The role of Southern Ocean mixing and upwelling in glacialinterglacial atmospheric $\mathrm{CO}_{2}$ change. Tellus B 58, 73-87. https://doi.org/10.1111/j.16000889.2005.00167.x

Watson, A.J., Vallis, G.K., Nikurashin, M., 2015. Southern Ocean buoyancy forcing of ocean ventilation and glacial atmospheric $\mathrm{CO}_{2}$. Nat. Geosci. 8, 861-864. https://doi.org/10.1038/ngeo2538

Yu, J., Elderfield, H., 2007. Benthic foraminiferal B/Ca ratios reflect deep water carbonate saturation state. Earth Planet. Sci. Lett. 258, 73-86. https://doi.org/10.1016/j.epsl.2007.03.025

Yu, J., Elderfield, H., Jin, Z., Booth, L., 2008. A strong temperature effect on U/Ca in planktonic foraminiferal carbonates. Geochim. Cosmochim. Acta 72, 4988-5000. https://doi.org/10.1016/j.gca.2008.07.011

Zech, R., 2012. A permafrost glacial hypothesis - Permafrost carbon might help explaining the Pleistocene ice ages. Quat. Sci. J. 61, 84-92. https://doi.org/10.3285/eg.61.1.07

Zheng, Y., Anderson, R.F., van Geen, A., Fleisher, M.Q., 2002. Remobilization of authigenic uranium in marine sediments by bioturbation. Geochim. Cosmochim. Acta 66, 1759-1772. https://doi.org/10.1016/S00167037(01)00886-9

Ziegler, M., Diz, P., Hall, I.R., Zahn, R., 2013. Millennial-scale changes in atmospheric $\mathrm{CO}_{2}$ levels linked to the Southern Ocean carbon isotope gradient and dust flux. Nat. Geosci. 6, 457-461. https://doi.org/10.1038/ngeo1782 


\section{Figures}

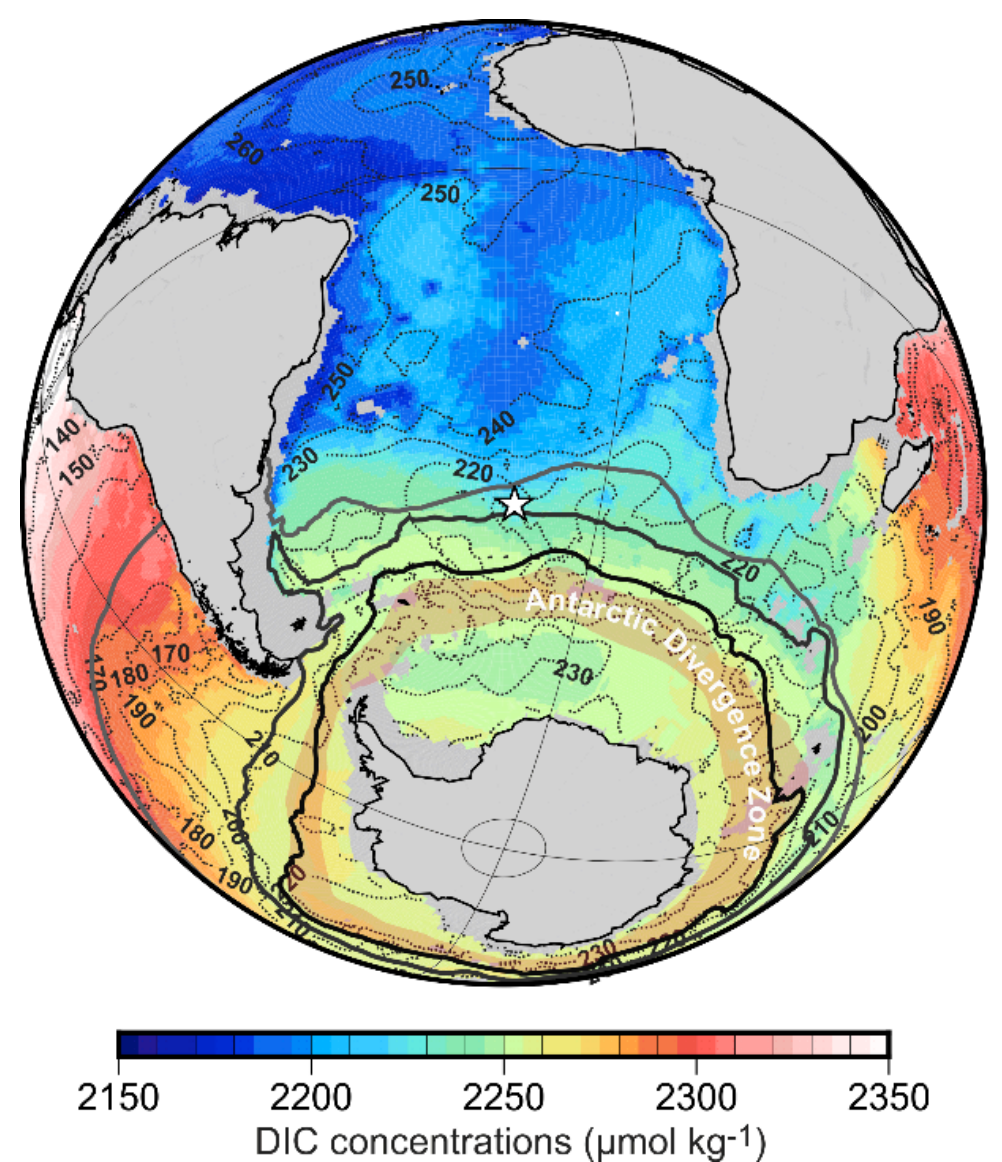

Fig. 1. Location of study site. Concentration of dissolved inorganic carbon (DIC, shaded; Key et al., 2004 ) in the ocean averaged below $2.5 \mathrm{~km}$ water depth. Contours indicate the average seawater dissolved $\left[\mathrm{O}_{2}\right]$ below $2.5 \mathrm{~km}$ water depth (Garcia et al., 2014). The location of sediment cores MD073076Q and MD07-3077 is indicated by a star. Major fronts are shown as stippled lines from south to north: Polar Front (dark grey line), sub-Antarctic Front (grey line) and sub-Tropical Front (light grey line) (Orsi et al., 1995; Sokolov and Rintoul, 2009). The Antarctic Divergence Zone is highlighted by an orange circumpolar band, representing the region of strong positive air-sea $\mathrm{CO}_{2}$ fluxes in austral winter in the Southern Ocean at present-day (see maps in Takahashi et al., 2002). 

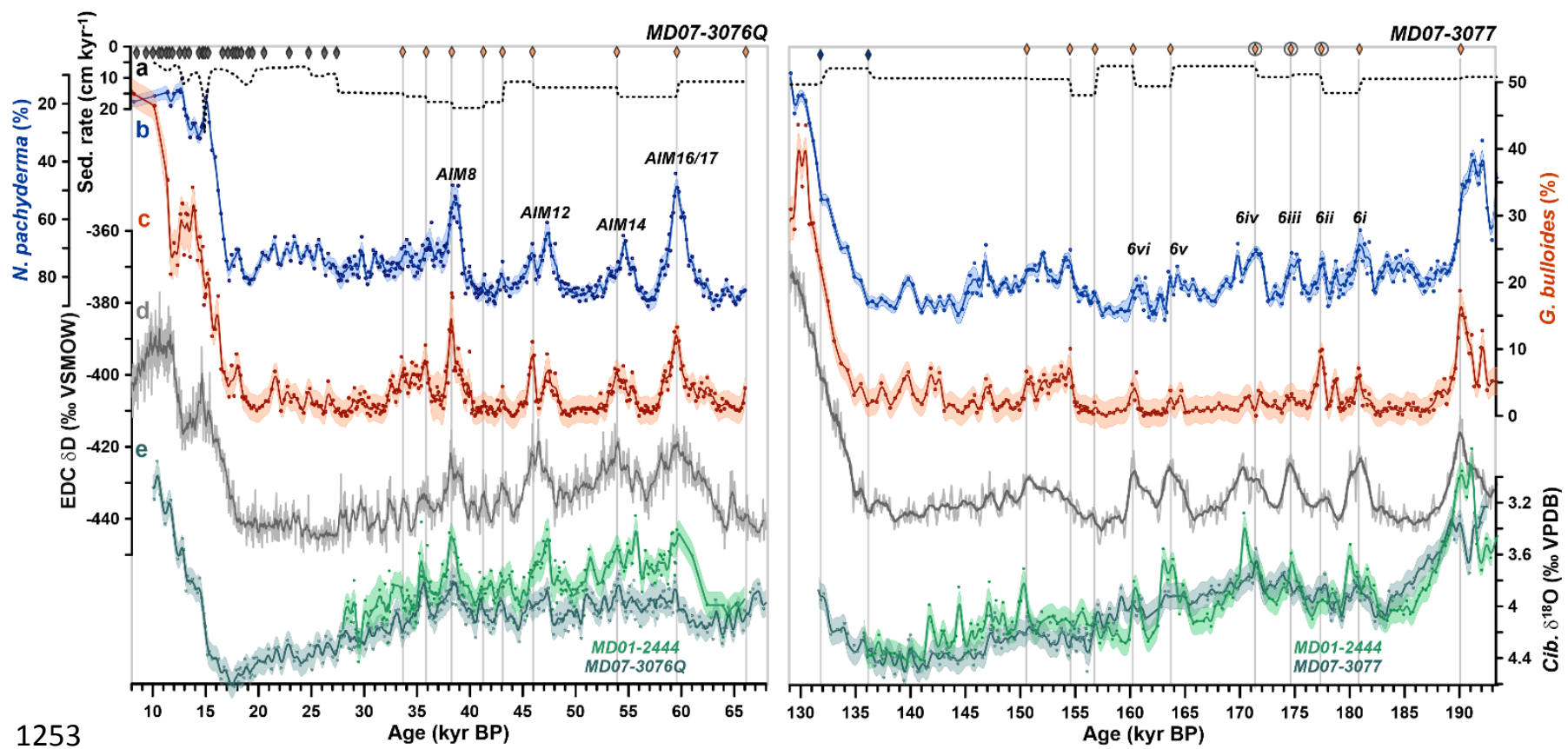

Fig. 2. Chronologies of sediment cores MD07-3076Q (Termination (T) I and Marine Isotope Stage (MIS) 3, left) and MD07-3077 (TII and MIS 6, right). (a) Sedimentation rate (line) and tiepoints (grey: ${ }^{14} \mathrm{C}$ dates, alignment of abundance variations of $G$. bulloides (orange) and $N$. pachyderma (blue) with EPICA Dome C (EDC) $\delta D$; Gottschalk et al., 2016a; Channell et al., 2017), (b) abundance changes of $N$. pachyderma, (c) abundance changes of G. bulloides, (d) EDC $\delta D$ (Jouzel et al., 2007) shown on the AICC2012 chronology (Bazin et al., 2013; Veres et al., 2013) and (e) C. kullenbergi $\delta^{18} \mathrm{O}$ records in comparison to mean benthic $\delta^{18} \mathrm{O}$ records from the Iberian margin (Skinner et al., 2007; MD01-2444; Margari et al., 2010). Lines and envelopes in (b), (c) and (e) show 500 yearsrunning averages and $2 \sigma$-uncertainties, respectively. Diamonds at the top of each panel show age markers obtained by ${ }^{14} \mathrm{C}$ dating of planktic foraminifera (dark grey) and a stratigraphic alignment of abundance variations of G. bulloides and N. pachyderma with EDC $\delta \mathrm{D}$ (light grey) (Channell et al., 2017). Encircled symbols show adjusted age markers that differ from the chronology for this core sequence published in Channell et al. (2017), as described in the text. The annotation of Antarctic warming events (AIM - Antarctic Isotope Maxima) follows EPICA Community Members (2006) for 


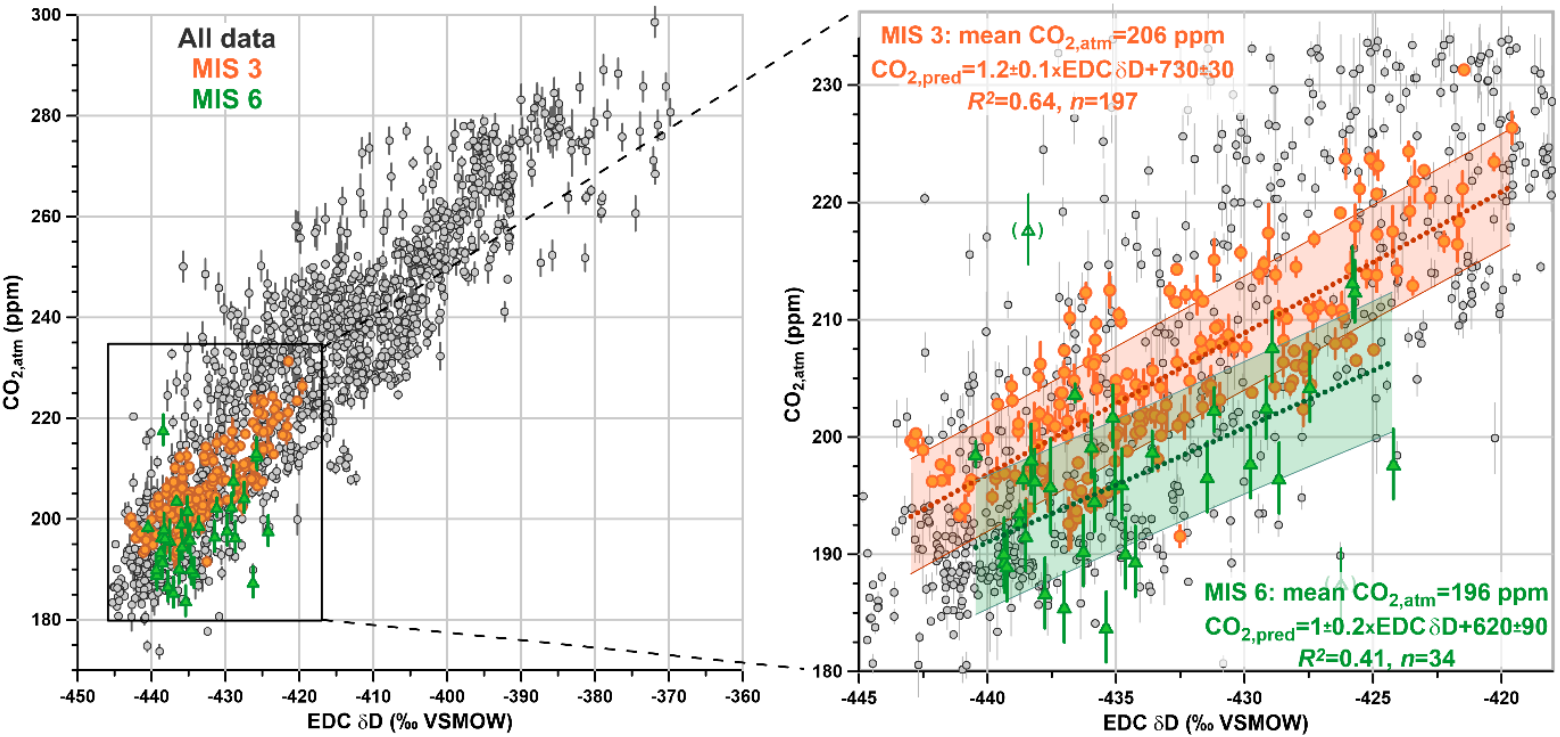

Fig. 3. Prediction of atmospheric $\mathrm{CO}_{2}$ levels $\left(\mathrm{CO}_{2, \text { atm-PRED }}\right)$ during MIS 6 based on $\delta \mathrm{D}$ variations in the EPICA Dome C (EDC) ice core. Linear regression model between EDC $\delta D$ (Jouzel et al., 2007) and $\mathrm{CO}_{2, \text { atm }}$ concentrations (Bereiter et al., 2015) for 63-32 kyr BP (MIS 3, orange: $\mathrm{CO}_{2, \text { atm-PRED }}=$ $1.2 \pm 0.1 \times(\mathrm{EDC} \delta \mathrm{D})+730 \pm 30)$ and for $183-134.5 \mathrm{kyr}$ BP (MIS 6, green: $\mathrm{CO}_{2 \text {,atm-PRED }}=1 \pm 0.2 \times(\mathrm{EDC}$ $\delta \mathrm{D})+620 \pm 90$ ), excluding two bracketed outliers), used as a transfer function to predict $\mathrm{CO}_{2, \text { atm }}$ during MIS 3 and MIS 6, respectively. Gray symbols show all ice core data from 800-2 kyr BP. Envelopes (right) show the $1 \sigma$-uncertainties of the regression models. 


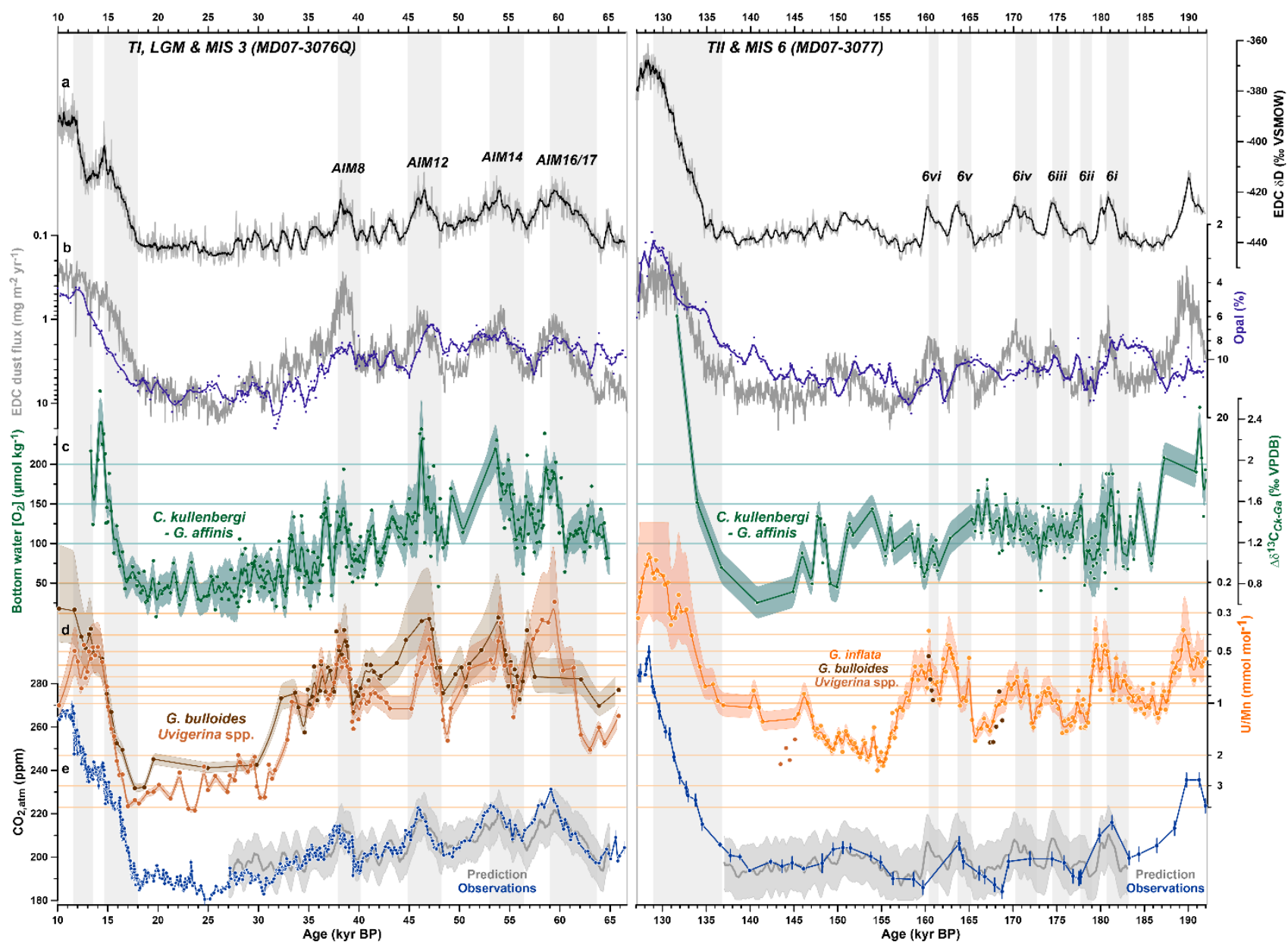

Fig. 4. Deep-ocean oxygenation- and productivity changes in the South Atlantic during TI and

MIS 3 (left, MD07-3076Q), and TII and MIS 6 (right, MD07-3077). (a) EDC $\delta D$ (Jouzel et al., 2007), (b) EDC dust fluxes (grey; Lambert et al., 2012) and sedimentary opal content at our study site (purple, corrected for incomplete water removal as in Supplementary Fig. S1), (c) difference between C. kullenbergi $\delta^{13} \mathrm{C}(C k)$ and $G$. affinis $\delta^{13} \mathrm{C}(G a), \Delta \delta^{13} \mathrm{C}_{C k \text {-Ga }}$, and corresponding bottom water $\left[\mathrm{O}_{2}\right]$ after Hoogakker et al. (2015), see Supplementary Fig. S3 for individual benthic foraminifer $\delta^{13} \mathrm{C}$ records, (d) U/Mn ratios of G. bulloides (dark brown), Uvigerina spp. (light brown) and G. inflata (or-

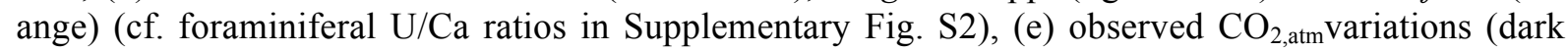

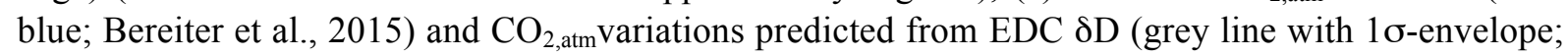
cf. Fig.3) for MIS 3 (left) and MIS 6 (right). Lines and envelopes in (b) to (d) represent 500 yr-running averages and $1 \sigma$-uncertainties, respectively. The lower uncertainty range of $G$. inflata $\mathrm{U} / \mathrm{Mn}$ is truncated at $0.08 \mathrm{mmol} \mathrm{mol}^{-1}$. Grey bars indicate intervals of rising $\mathrm{CO}_{2, \mathrm{~atm}}$. 


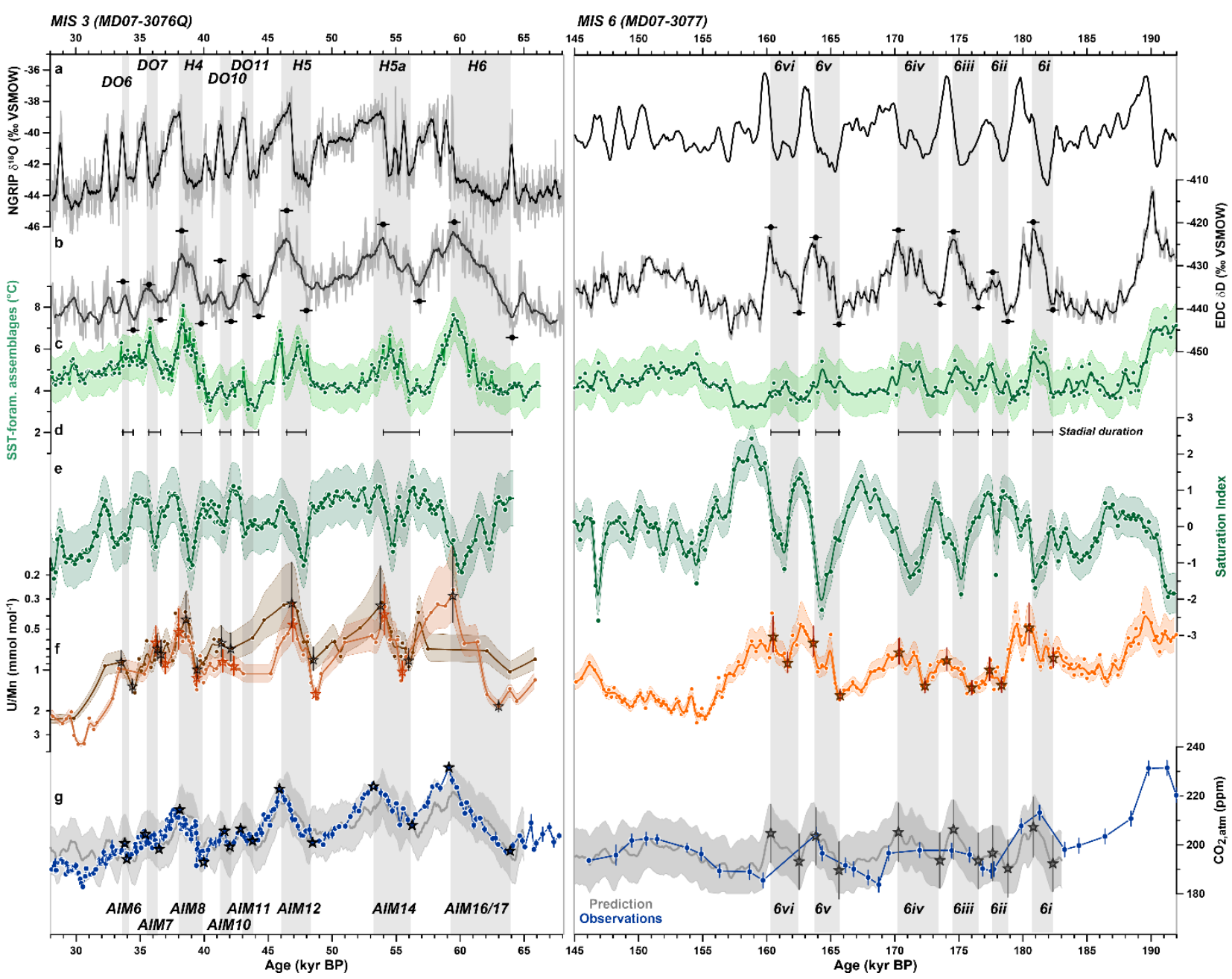

Fig. 5. Millennial-scale $\mathrm{CO}_{2, \text { atm }}$ variations compared to changes in carbonate saturation and bottom water oxygenation in the deep sub-Antarctic Atlantic during MIS 3 (left, MD07-3076Q) and MIS 6 (right, MD07-3077). (a) Observed (MIS 3: NGRIP members, 2004) and predicted NGRIP $\delta^{18} \mathrm{O}$ variations (MIS 6: Barker et al., 2011), (b) EDC $\delta D$ (grey; Jouzel et al., 2007) and symbols highlighting the onset and ends of northern-hemisphere stadials according to Margari et al. (2010) (black), (c) summer sea surface temperatures (green; SST) derived from planktic foraminiferal assemblage counts in the study cores and the calibration of Haddam et al. (2016), (d) stadial durations (i.e., duration of Antarctic warming) according to Margari et al. (2010), (e) saturation index as defined in Gottschalk et al., (2015a) and shown in Supplementary Fig. S4, (f) authigenic-coating U/Mn ratios of G. bulloides (dark brown), Uvigerina spp. (light brown) and G. inflata (orange), stars indicate onsets and ends of gradual U/Mn change associated with northern-hemisphere stadials, $(\mathrm{g})$ observed $\mathrm{CO}_{2, \text { atm }}$ concentrations (dark blue; Bereiter et al., 2015) and $\mathrm{CO}_{2, \text { atm-PRED }}$ (grey) for MIS 3 (left) and MIS 6 (right), stars indicate onsets and ends of $\mathrm{CO}_{2, \text { atm }}$ change associated with northern-hemisphere stadials. Grey bars indicate intervals of rising $\mathrm{CO}_{2, \mathrm{~atm}}$. . Annotations of Dansgaard-Oeschger (DO)-, Heinrich (H) events and AIMs follow Dansgaard et al. (1993), Hemming (2004), EPICA Community Members (2006) and Margari et al. (2010), respectively. 

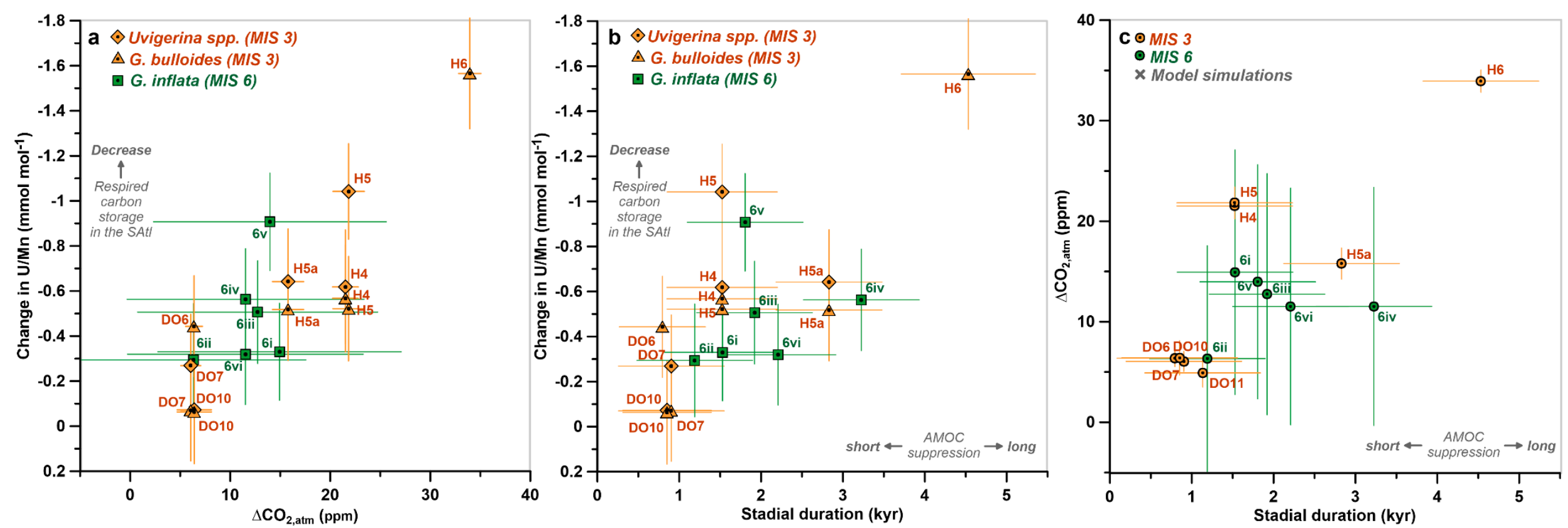

Fig. 6. Variations in $\mathrm{CO}_{2, \text { atm }}$ levels during stadials and associated changes in respired carbon content at our study site. (a) Change in foraminiferal U/Mn versus parallel change in $\mathrm{CO}_{2, \text { atm }}$ (i.e., based on observations in MIS 3 and our MIS 6 prediction), (b) change in foraminiferal U/Mn ratios versus the duration of northern hemisphere stadials following Margari et al. (2010) and (c) change in $\mathrm{CO}_{2, \text { atm }}$ (i.e., based on observations in MIS 3 and our MIS 6 prediction) versus the duration of stadial conditions (circles). In (c) we also compare our proxy data with simulated $\mathrm{CO}_{2 \text {,atm }}$ changes during stadials in freshwater hosing experiments in the North Atlantic (crosses; see review of Gottschalk et al., 2019). Data based on G. inflata, Uvigerina spp. and G. bulloides are shown as squares, diamonds and triangles, respectively. Time intervals are annotated as in Fig. 5. AMOC - Atlantic Meridional Overturning Circulation; SAtl - South Atlantic. 


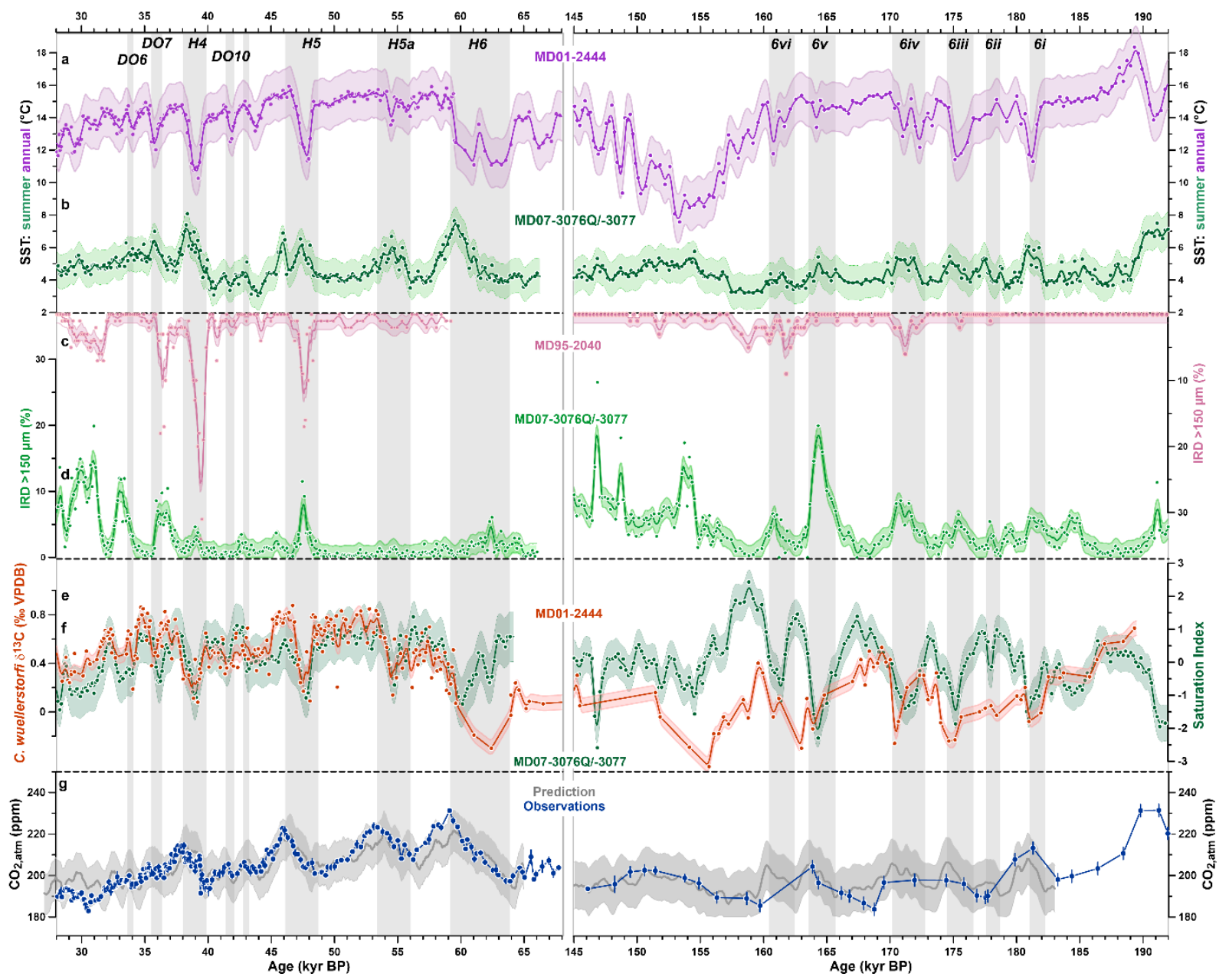

Fig. 7. Comparison of climate variability in the South Atlantic and the North Atlantic Ocean reconstructed in (a) sediment core MD01-2444 based on alkenone unsaturation indices (annual mean SST, purple; Martrat et al., 2007) and (b) MD07-3076Q/-3077 based on planktic foraminiferal assemblage counts (summer SST, green; this study), changes in the abundance of ice-rafted debris (IRD) in (c) MD95-2040 (de Abreu et al., 2003; age model based on Margari et al. 2010) and (d) MD073076Q/-3077 (this study), changes in the variability of the Atlantic Meridional Overturning Circulation $(\mathrm{AMOC})$ recorded in (e) epibenthic foraminiferal $\left(C\right.$. wuellerstorfi) $\delta^{13} \mathrm{C}$ changes in core MD012444 (2.6 km water depth) (brown; Skinner et al., 2007; Margari et al., 2010), (f) carbonate saturation indices in core MD07-3076Q/-3077 (green; Gottschalk et al., 2015a; this study), and (g) observed

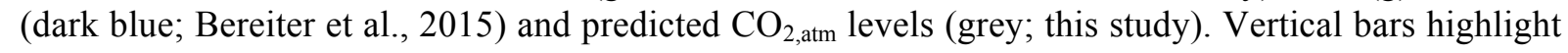
intervals of rising $\mathrm{CO}_{2, \text { atm }}$ concentrations. Solid lines and error envelopes show 500 year-running averages. The error envelopes refer to $1 \sigma$-calibration uncertainties: (a) $1.5^{\circ} \mathrm{C}$ (Martrat et al., 2007), (b) $\sim 1^{\circ} \mathrm{C}$ (this study), $1 \sigma$-uncertainties of the IRD counts, i.e., (c) $1.5 \%$ (conservative estimate; de Abreu et al., 2003) and (d) $1.5 \%$ (this study), (e) the external $\delta^{13} \mathrm{C}$ reproducibility of carbonate standards $(1 \sigma=0.06 \%)$, (f) the $1 \sigma$-uncertainties of the saturation index, and $(\mathrm{g})$ the $1 \sigma$-uncertainties of predicted $\mathrm{CO}_{2 \text {,atm }}(\sim 12$ ppm, cf. Fig. 3). All data are shown on the GICC05 or equivalent AICC2012 age scales. 


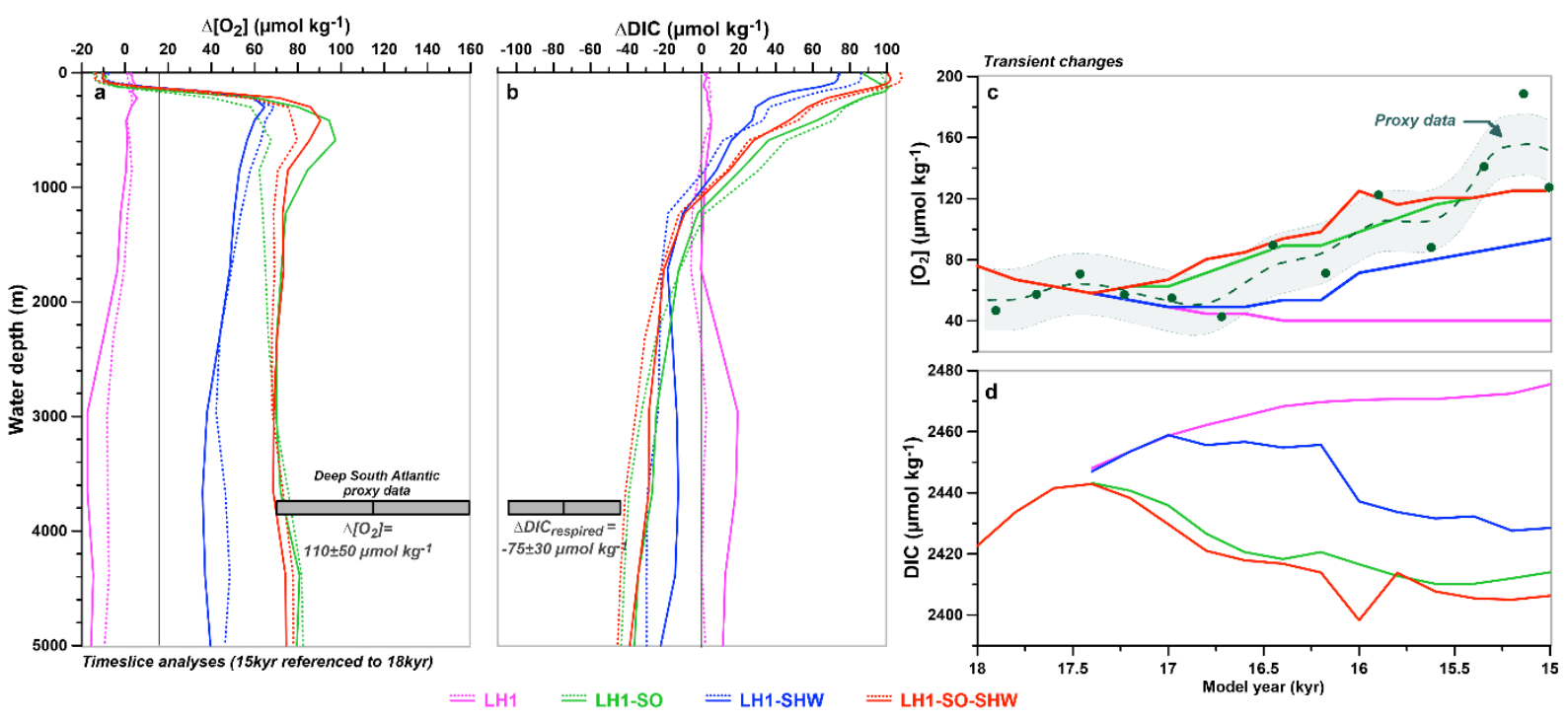

Fig. 8. Geochemical fingerprints of different forcings of millennial-scale $\mathrm{CO}_{2, \text { atm }}$ variations in transient climate model simulations with LOVECLIM (Menviel et al., 2018). Water column profiles of (a) $\left[\mathrm{O}_{2}\right]$ - and (b) DIC-anomalies averaged over the South Atlantic (solid lines; $60^{\circ} \mathrm{W}-20^{\circ} \mathrm{E}, 40$ $70^{\circ} \mathrm{S}$ ) and the Southern Ocean (stippled lines; $40-70^{\circ} \mathrm{S}$ ). Simulated transient changes of $(\mathrm{c})\left[\mathrm{O}_{2}\right]-$ and (d) DIC-anomalies at our South Atlantic core site (lines) compared to reconstructed bottom water $\left[\mathrm{O}_{2}\right]$ in core MD07-3076Q (see Fig. 4). The depth profiles show anomalies at model year 15 ka referenced to background levels at model year $18 \mathrm{ka}$, and represent a $\mathrm{H} 1$ anomaly. The simulations apply transient changes in orbital parameters and in northern-hemisphere ice sheet characteristics for $\mathrm{H} 1$, and force a shutdown of the AMOC through time-varying freshwater supply in the North Atlantic (simulation 'LH1'). They additionally stimulate increased Southern Ocean convection through prescribed changes in the surface buoyancy fluxes without (simulation 'LH1-SO')or with intensification of the SHW wind stress (simulation 'LH1-SO-SHW'), or in fact with stronger SHW winds only (simulation 'LH1-SHW'). Gray bars indicate mean changes and $1 \sigma$-uncertainties of bottom water $\left[\mathrm{O}_{2}\right]$ and respired DIC levels at depth during millennial-scale rises in $\mathrm{CO}_{2, \text { atm }}$ during MIS 3 derived from proxy reconstructions in core MD07-3076Q (Fig. 4; Gottschalk et al., 2016b). 